University of Rhode Island

DigitalCommons@URI

Open Access Dissertations

1974

\title{
Thiol Amino Acids in Quality Control and Nutritive Value of Fishery Products
}

Mohsin Ali

University of Rhode Island

Follow this and additional works at: https://digitalcommons.uri.edu/oa_diss

\section{Recommended Citation}

Ali, Mohsin, "Thiol Amino Acids in Quality Control and Nutritive Value of Fishery Products" (1974). Open Access Dissertations. Paper 566.

https://digitalcommons.uri.edu/oa_diss/566

This Dissertation is brought to you for free and open access by DigitalCommons@URI. It has been accepted for inclusion in Open Access Dissertations by an authorized administrator of DigitalCommons@URI. For more information, please contact digitalcommons-group@uri.edu. 
THIOL AMINO ACIDS IN QUALITY CONTROL AND NUTRITIVE VALUE OF FISHERY PRODUCTS

By

MD. MOHSIN ALI

A DISSERTATION SUBMITTED IN PARTIAL FULFILLMENT OF THE REQUIREMENTS FOR THE DEGREE OF DOCTOR OF PHILOSOPHY

IN BIOLOGICAL SCIENCES 


\section{DOCTOR OF PHILOSOPHY DISSERTATION \\ $\mathrm{OF}$}

MD. MOHSIN ALI

Approved:

Dissertation Committee:

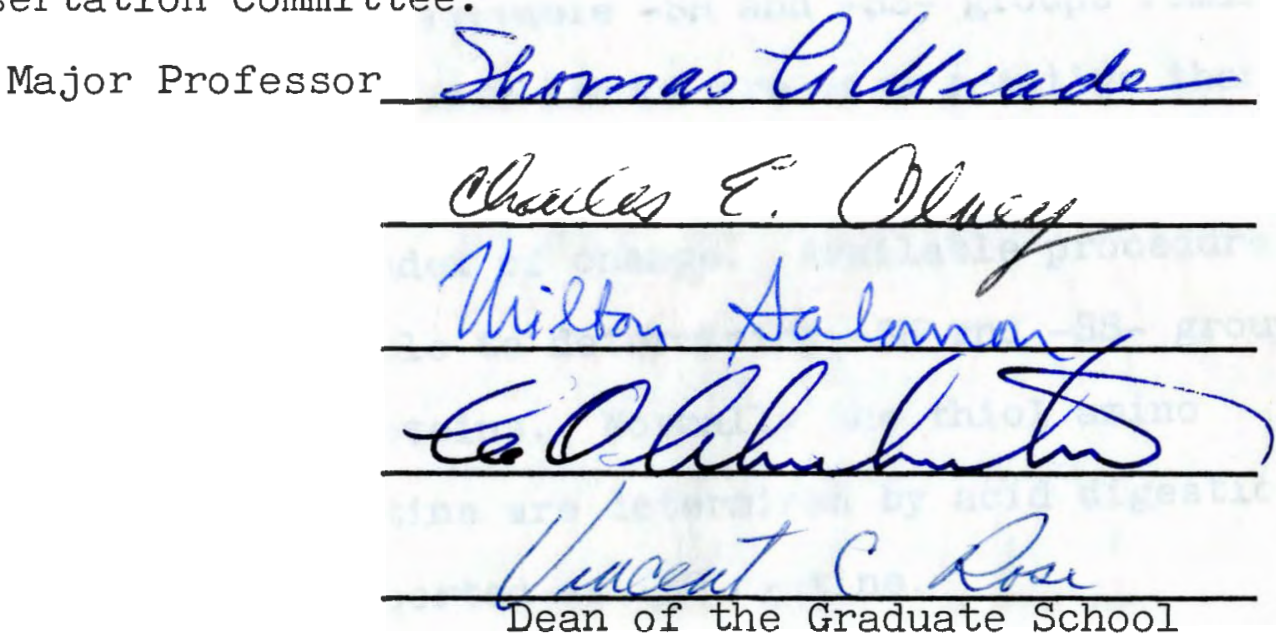

UNIVERSITY OF RHODE ISLAND

1974 


\section{ABSTRACT}

The quality of fish products is dependent upon the raw material and the process employed for their reproduction. The availability of the amino acids present in the protein component determine the value of the product as a food supplement. Amino acid availability can be determined by chemical, biochemical and biological methods. Most of the procedures are rather lengthy. A widely used chemical procedure, the available lysine method, is based on determining the quality of total lysine having free or reactable epsilon amino groups. This research has been directed toward the development of a procedure for determining the quantity of reactable -SH and -SS- groups remaining in the protein, as these groups are more reactive than the epsilon amino groups of lysine and should therefore provide a more critical index of change. Available procedures are not readily adaptable to determining -SH and -SS- groups in intact insoluble proteins. Normally the thiol amino acids cysteine and cystine are determined by acid digestion of the proteins and reported as $1 / 2$ cystine.

The procedure developed essentially involves a carefully controlled fish protein solubilization with a selected enzyme, followed by titration with $\mathrm{AgNO}_{3}$ using a $\mathrm{Ag} / \mathrm{S}$ specific-ion electrode to determine the quantity of titratable -SH groups. By reducing -SS- groups prior to titration 
the combined -SH and -SS- level can be determined. Subtracting the previous -SH value from the total gives the -SS- level.

The results obtained when this procedure was used to determine the thiol amino acids content of a series of specially prepared and selected fish products, were considerably lower than those obtained by the use of an amino acid autoanalyzer but exhibited a high degree 'of' correlation. The results also showed a high degree of correlation with those obtained by pepsin digestion, another procedure for determining protein quality. When the specially prepared and selected fish products were biologically assayed, using one week old White Rock chicks, differences in response were observed that indicated a trend but a high degree of correlation was not established. The results of the biological assay suggest that the procedure was not sufficiently sensitive to detect the small difference in the thiol amino acids present in the diet.

The effect of selected process conditions on the level of thiol amino acids in the end products was determined. The results strongly suggest that two factors contribute to the loss of thiol groups; cooking in the wet reduction process and post-drying autoxidation of residual lipids in products prepared by wet reduction and by alcohol dehydration.

In the herring product $\left(\mathrm{FP}_{8}\right)$, in which residual lipids were allowed to oxidize, the $1 / 2$ cystine level was reduced by 
$40 \%$ in comparison to the product $\left(\mathrm{FP}_{7}\right)$ prepared from the same lot of herring in which the lipids did not undergo oxidation. Among the menhaden products, the combination of cooking, drying and lipid oxidation which occurred during the production of fish meal $\left(\mathrm{FP}_{11}\right)$ resulted in a $45 \%$ reduction in the level of $1 / 2$ cystine. Cooking of menhaden followed by alcohol dehydration and lipid extraction $\left(\mathrm{FP}_{10}\right)$, resulted in a $23 \%$ reduction in the level of $1 / 2$ cystine. Those products in which the lipids were allowed to oxidize were devoid of -SH groups available for titration with $\mathrm{AgNO}_{3}$.

The following table summarizes the thiol amino acid determinations made using the amino acid autoanalyzer and the ionalyzer methods.

Thiol Amino Acids

Fish Products
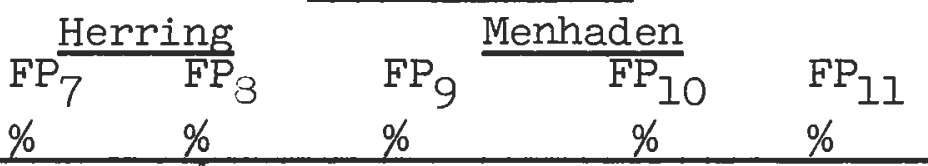

$1 / 2$ cystine

$\begin{array}{llllll}\text { AAA method } & 1.00 & 0.60 & 1.10 & 0.85 & 0.60 \\ \text { Ionalyzer method } & 0.36 & 0.22 & 0.44 & 0.28 & 0.22\end{array}$
cysteine
Ionalyzer method
0.11
0.00
0.16
$0.10 \quad 0.00$

Thus, a rapid procedure for determining thiol amino acids that shows good correlation with other widely used procedures for determining protein quality has been developed and evaluated in a series of selected and prepared fish products. 


\section{ACKNOWLEDGEMENTS}

I am grateful to and would like to thank Dr. Thomas L. Meade of the Department of Animal Science, and Fisheries and Marine Technology for his guidance, valuable counsel and for his suggestions on the preparation and review of this dissertation.

Appreciation is extended to Dr. Charles E. Olney, Dr. Clinton 0. Chichester and Dr. Milton Salomon for their valuable suggestions and moral support; to the United States A.I.D. for continuing as my sponsor, and to the Government of the People's Republic of Bangladesh for allowing me to continue my studies abroad.

Messrs Lipman, Marine Inc., State Pier, Gloucester, Massachusetts, who supplied menhaden press-cake and menhaden fish meal, and Point Judith Fisherman's Co-operative, Point Judith, Rhode Island, who supplied fresh herring and menhaden fish, are gratefully acknowledged.

I thank Hena, my wife, for her constant encouragement throughout.my education abroad and for taking care of the family alone.

This project is financed by the National Sea Grant Program and the Agricultural Experimentation Station, College of Resource Development, University of Rhode Island, Kingston, Rhode Island. 


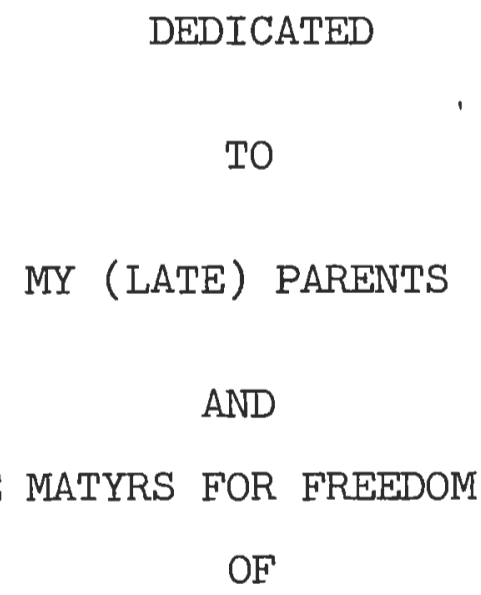

BANGLADESH

IN

1971 
TABLE OF CONTENTS

Chapter

Page

I. INTRODUCTION................... I

II. REVIEW OF IITERATURE................. 3

Chemistry and Biochemistry of TAA........

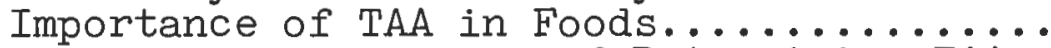
Review on Methodology of Determining TAA..

III. MATERIALS AND METHODS................. 19

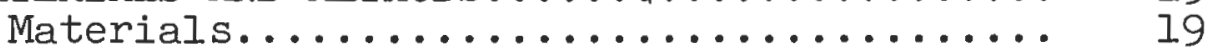

Fish and Fish Products.............. 19

Experimental Animals............. 19

Ionalyzer and Specific-ion Electrode.... 23

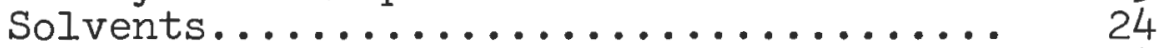

Chemicals and Bio-chemicals.......... 24

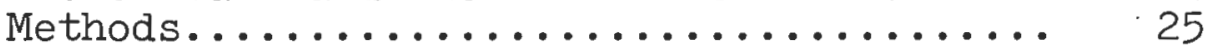

Method of Processing Fish and Press-cake 25

Analytical Methods................ 27

Bio-assay of Fish Proteins........... 28

IV. EXPERIMENTAL.................... 29

The Preparation of FP................. 29

Evaluation of Nutritional Quality of Fish

Products $\left(\mathrm{FP}_{7}-\mathrm{FP}_{11}\right)$ by Chick Bio-assay

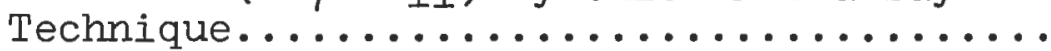

Development of a Method for Determining

TAA in Proteins of Fish Products using

$\mathrm{Ag} / \mathrm{S}$ Specificion-ion Electrode -

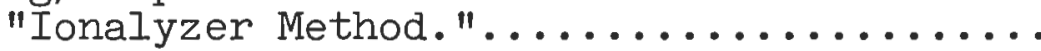

V. DISCUSSION..................... 76

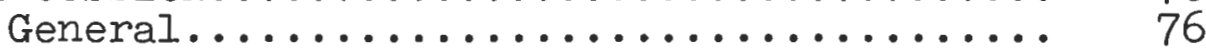

Fish Product Definitions............. 77

Selection of Fish................ 78

Selection of Methods for Processing Fish

for Evaluation of Nutrional Quality of

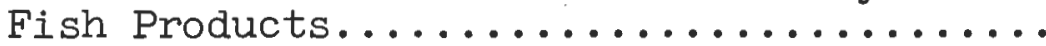

Selection of Method for Hydrolyzing Pro-

tein in Fish Products................ 80

Selection of Enzyme for Hydrolyzing Pro-

tein in Fish Products................. 81

The Effects of Processing on Fish Proteins 81

The Effects of Processing on Nutritional

Quality............................ 84

Estimation of Thiol Amino Acids by

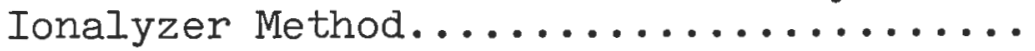


TABLE OF CONTENTS (Continued)

Chapter

Page

VI. CONCLUSIONS AND RECOMMENDATIONS.......... 92

Conclusions...................... 92

Recommendations.................... 95

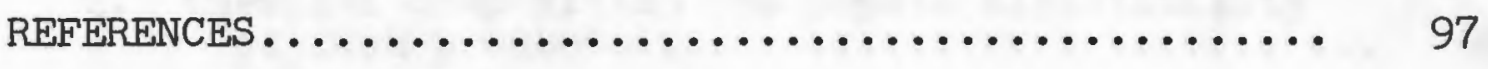

APPENDIX A....................................... 104 


\section{LIST OF TABLES}

Table

Page

1. Chemical composition of ground whole fish...... 48

2. Chemical composition and pepsin digestibility

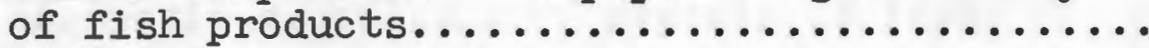

3. Amino acid composition of fish products....... 50

4. Relationship between lipid oxidátion and TAA

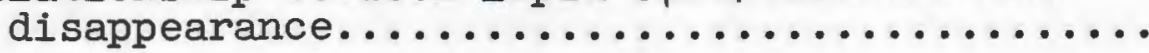

5. Experimental diets $(21 \%$ protein).......... 53

6. Experimental diets (18\% protein)........... 54

7. Composition of vitamins and trace element mixtures for experimental diets........... 55

8. Distribution of birds in pens for testing experimental diet $(2 l \%$ protein).............. 56

9. Distribution of birds in pens for testing experimental diet (18\% protein)...............

10a. Results of ten-day bio-assay of fish products using experimental diets (2l\% protein)...... 58

10b. Results of a ten-day bio-assay of fish products using experimental diets (18\% protein)...... 59

11. Amino acid requirements, amino acid comparison of experimental diets (2l\% protein) and F:G by a chick in a 10-day feeding test...........

12. Amino acid requirement, amino acid comparison of experimental diets ( $18 \%$ protein) and $\mathrm{F}: \mathrm{G}$ by a chick in a 10-day feeding test.........

13. Recovery of -SH compounds dissolved in distilled water by Ionalyzer method................

14. Study to find out a suitable media for titrating -SH compounds using AgNO3 by Ionalyzer method.

15. Selection of enzyme for hydrolyzing protein of

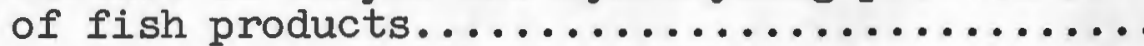




\section{LIST OF TABLES (Continued)}

Table

16. Change in $\mathrm{pH}$ of $0.1 \mathrm{M}$ imidazole buffer during enzymatic hydrolysis of protein of fish

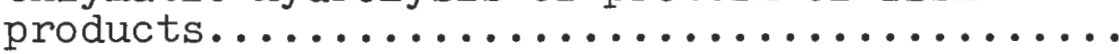

17. Comparison of cystine values determined by Ionalyzer method and amino acird Autoanalyzer

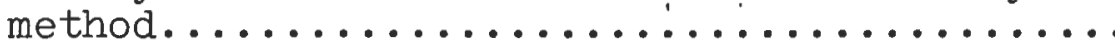

18. Effect of enzyme concentration on hydrolysis of

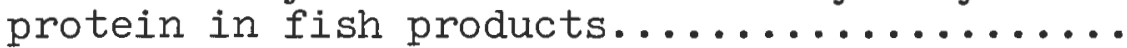

19. Effect of suspended particles on determination of TAA in protein hydrolyzate of fish products...

20. Effect of urea concentration on determination of TAA in protein hydrolyzate of fish products...

21. Optimum $\mathrm{pH}$ temperature for hydrolyzing protein from fish products with subtilisin BPN'...... 70

22. Optimum for hydrolyzing protein from fish products with subtilisin $\mathrm{BPN}^{\prime} . \ldots \ldots \ldots \ldots \ldots \ldots \ldots$

23. Period of digestion of protein from fish pro-

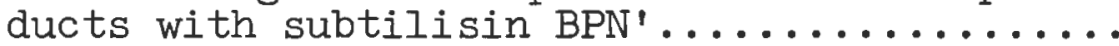

24. Enzyme (subtilisin BPN') concentration on digestibility of protein from fish products....

25. Comparison of thiol amino acids content in fish products by Ionalyzer and amino acid Autoan-

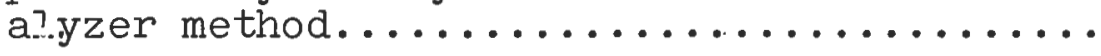

26. The observed potential and the change of potential on titrating the protein hydrolyzate of fish products $\mathrm{FP}_{7} \ldots \ldots \ldots \ldots \ldots \ldots \ldots \ldots \ldots$ 


\section{INTRODUCTION}

The thiol amino acids (TAA) which are part of the sulfur amino acid (SAA) group have been the subject of intensified research by biochemists and nutritionists. In recent years, it has been shown that either cystine or cysteine can meet from 30-50\% of the SAA requirement for livestock and poultry.

In the developed countries of the world, poultry has become a major source of animal protein. Economical production of poultry and eggs is dependent upon an adequate supply of supplemental proteins, an important one being fish meal. Fish meal is also widely used in the diets of swine and a new market is developing in formulated fish diets. Fish farming, as a means of increasing the available supplies of animal protein, is gaining momentum all over the world. Acceptance of fish as food varies between countries and ranges from its use as a primary source of animal protein to providing an alternative to other forms such as beef, lamb, pork and poultry.

Fish protein quality has been the subject of research for many years and the establishment of factors that affect quality has been elusive. The susceptibility of TAA to deterioration change, although recognized, has not been 
studied in relation to fish meal quality. The effects of oxidative change of thiols and disulfides on the nutritive value of fish proteins has been reported by Matsuo [1962], and by Roubal and Tappel [1966]. Moist heat can also bring about changes in thiols [Anon. 1952]. The effects of heating during the curing, storage and transport of fish meal has been reviewed by Dreosti [1973].

Changes in fish protein TAA may occur during storage of fish as a result of autolytic and microbial spoilage, during processing and during subsequent handling of the dehydrated product prior to use. This study is limited to the investigation of selected steps in processing and end product handling in an effort to minimize deteriorative changes of TAA.

Older analytical procedures for determining thiol are both cumbersome and lengthy. A relatively new procedure for the determination of thiol and disulfide groups in soluble proteins, utilizing a silver/sulfide ( $\mathrm{Ag} / \mathrm{S}$ ) specific-ion electrode has been developed by Harrap and Gruen [1971]. This procedure has been adapted to enable its use for the assay of thiol and disulfide content of denatured proteins, including fish meal and fish protein concentrate (FPC) after solubilization with selected enzymes. The effect on TAA of processing fish to fish meal and FPC have been determined using the $\mathrm{Ag} / \mathrm{S}$ specific-ion electrode and a Technicon Amino Acid Autoanalyzer. An attempt to correlate the results of biochemical determinations to biological response was carried out. 


\section{II}

REVIEW OF LITERATURE

Chemistry and Biochemistry of the TAA

General Chemical Reactions of the TAA

The thiol group (-SH) acts both'as an acid and as a base as per equations (a) and (b) [Roberts and Caserio, 1965].

(a) Acid reaction

$$
\mathrm{R}-\mathrm{SH}+\mathrm{NaSH} \longrightarrow \mathrm{R}-\mathrm{SNa}+\mathrm{H}_{2} \mathrm{~S}
$$

(b) Base reaction

$$
\mathrm{R}-\mathrm{SH}+\mathrm{R}_{1}-\mathrm{COOH} \longrightarrow \mathrm{R}-\mathrm{S}-\mathrm{CO}-\mathrm{R}_{1}+\mathrm{H}_{2} \mathrm{O}
$$

Oxidation Reactions of the TAA

The oxidation of thiols occurs easily. It takes place at least in three different ways.

(a) The mild oxidizing agents, e.g., atmospheric 02, halogens and $\mathrm{H}_{2} \mathrm{SO}_{4}$ produce disulfides (-SS-).

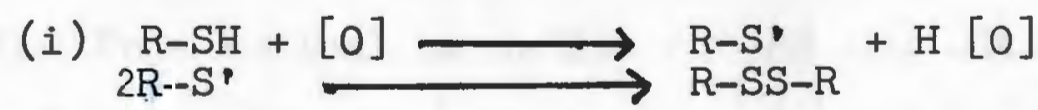

(ii) $\begin{array}{ll}\mathrm{R}-\mathrm{SH}+[\mathrm{O}] \longrightarrow \mathrm{R}-\mathrm{S}-\mathrm{OH} \\ \mathrm{R}-\mathrm{S}-\mathrm{OH}+\mathrm{R}-\mathrm{S}^{\prime} \longrightarrow \mathrm{R}-\mathrm{SS}-\mathrm{R}+\mathrm{OH}^{\prime}\end{array}$ 
(b) The vigorous oxidation of thiol with $\mathrm{HNO}_{3}$, permanganate and $\mathrm{H}_{2} \mathrm{O}_{2}$ gives sulfonic acid as shown below:

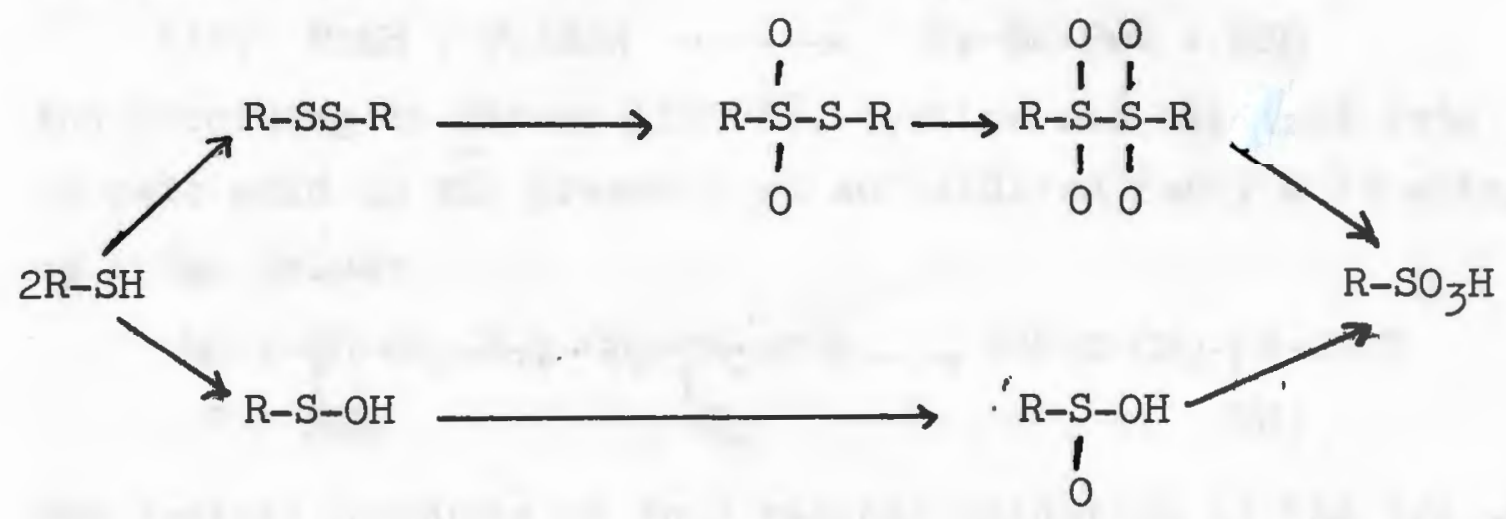

In biological systems both mild and vigorous oxidations of thiol take place. The classic example of mild oxidation of thiol is the conversion of cysteine nonenzymatically and reversibly to cystine by the reaction with glutathione [West and Todd, 1966].

Cysteine + G-SS-G Cystine + 2 G-SH

Hence cystine may also be termed as thiol amino acid although cysteine is the true thiol amino acid.

The example of vigorous oxidation of thiol in vivo is its oxidation to sulfate through cysteine sulfonic acid and cysteic acid [White, et al., 1968].

(c) Free radical oxidation of -SH and -SS-. The free radical oxidation degrades both thiol and disulfide [Matsuo, 1957B; Lewis and Wills, 1962; Buttkus, 1972 and Braddock and Dugan, 1973].

The free radical mechanism as proposed by Kuninori and Sullivan [1968], is as follows: 

(i) $\mathrm{R}-\mathrm{SH} \longrightarrow \mathrm{RS}^{\prime}+\mathrm{H}^{\prime}$
(ii) $\mathrm{RS}^{\prime}+\mathrm{PrS} \mathrm{S}^{\prime} \longrightarrow \mathrm{R}-\mathrm{SS}-\mathrm{Pr}$
(iii) $\mathrm{Pr}-\mathrm{S}^{\prime}+\mathrm{H}^{\prime} \longrightarrow \mathrm{Pr}-\mathrm{SH}$
(iv) $\mathrm{PrSH}+\mathrm{PrlSSR} \longrightarrow \mathrm{Pr}-\mathrm{SS}-\mathrm{PrI}+\mathrm{RSH}$

And according to Matsuo [1957B], cystine was oxidized into cysteic acid in the presence of autoxidized fatty acid esters as shown below:

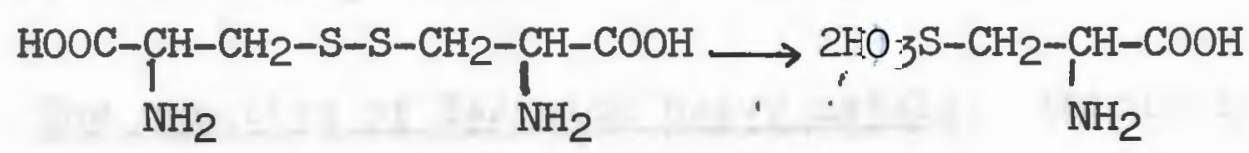

The typical products of free radical oxidation of TAA are -SS-, $\mathrm{SO}_{3}$ and -SOSO- have also been reported by Lewis and Wills [1962].

This type of oxidation occurs in the reduction of fish to meal as the polyunsaturated fish oils are prone to autooxidation in presence of heat and moisture.

Action of alkali on -SH and -SS-. Alkali can remove sulfur from proteins, and the following reaction has been proposed by Tarbell and Hamish [1951]:

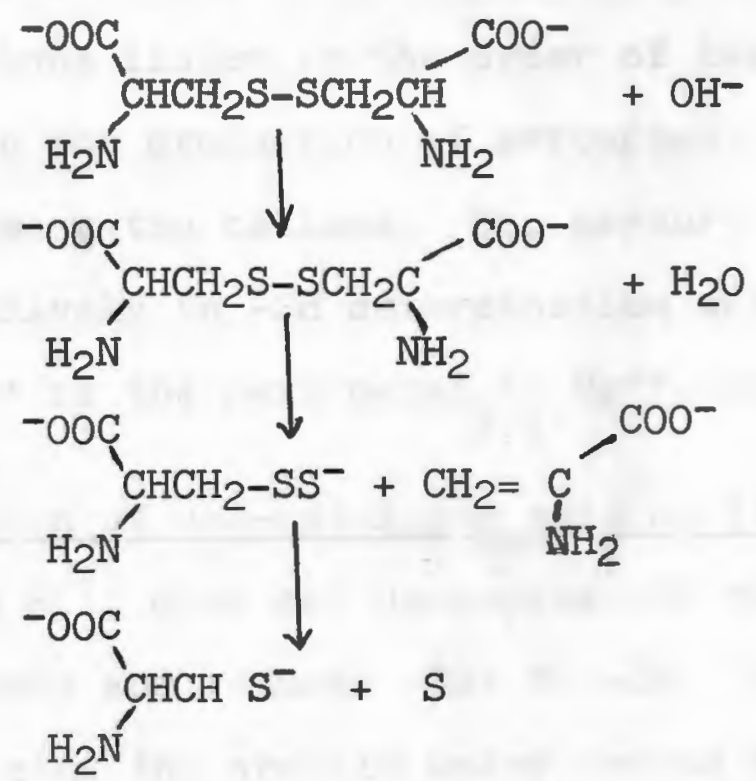


This reaction holds good for lanthionine, but thiols may react to produce sulfide ions [Dann, et al., 1957]. $\mathrm{Hg}^{+}$and $\mathrm{Ag}^{+}$accelerate the degradation reaction as per equations [Cecil and McPhee, 1959],

(i) $2 \mathrm{R}-\mathrm{SS}-\mathrm{R}+3 \mathrm{Hg}^{+}+2 \mathrm{H}_{2} \mathrm{O} \longrightarrow 3 \mathrm{RSHg}+\mathrm{RSO}_{2} \mathrm{H}+\mathrm{H}^{+}$

(ii) $2 \mathrm{R}-\mathrm{SS}-\mathrm{R}+3 \mathrm{Ag}^{+}+2 \mathrm{OH}^{-} \longrightarrow 3 \mathrm{RSAg}+\mathrm{RSO}_{2} \mathrm{H}+\mathrm{H}^{+}$

The reaction of TAA with heavy metals. Thiols form insoluble salts with heavy metals. This characteristic property of forming insoluble saits with heavy metals by thiols is the basis for the term, mercaptan. The metal-cysteine reaction system has been studied by many investigators and it has been reviewed by Gurd and Wilcox [1956]. It can briefly be summarized as follows:

$\begin{array}{ll}\mathrm{RSH}+\mathrm{M}^{+} \longrightarrow & \mathrm{R}-\mathrm{SM} \\ \text { Thiols Metal } & \text { Mercaptans }\end{array}$

$\mathrm{Hg}^{++}, \mathrm{Cu}^{+}, \mathrm{Ag}^{+}, \mathrm{Pb}^{++}, \mathrm{Cd}^{++}, \mathrm{Zn}^{++}, \mathrm{Cu}^{++}, \mathrm{Co}^{++}$, and $\mathrm{Mn}^{++}$ are metal ions listed in the order of their reactivity with cysteine in the production of mercaptan. $\mathrm{Hg}^{++}$is the most reactive among the cations. So, mercury compounds have been used extensively in -SH determination which will be reviewed later. $\mathrm{Ag}^{+}$is the next metal to $\mathrm{Hg}^{++}$used in - $\mathrm{SH}$ assay.

Action of non-oxidizing acid on TAA. A non-oxidizing acid, like $\mathrm{HCl}$, does not decompose - SH but hydrolizes the peptide bonds and reduces -SS- to $-\mathrm{SH}$. Hence it is utilized in hydrolizing the protein under vacuum to determine the amino acids in protein. 
The Functions of TAA in Biological Systems

The main functions of TAA in biological systems are as follows:

(a) Enzymatic activity. It has been suggested by Hellerman [1937] that -SS- form of the enzyme was inactive and that reduction of the -SS- group to active -SH groups activated the enzyme. Thus

Enzyme-SS-Enzyme+2H $\rightleftharpoons 2$ 'Enzyme-SH Inactive Active

Out of 40 enzymes listed by Singer [1946], it will be noted that over two-thirds of those studied require functioning thiol groups for their activity.

The proteolytic enzymes have been divided into ten groups. The cysteine protease group consisting of papain, chymopapain, ficin, bromelin and streptococcal protease all contain active -SH sites [Perlman and Lorand, 1970].

(b) The structure of the proteins. The disulfide bonds formed between cysteinyl residues of the same polypeptide chain are generally responsible for the maintenance of the tertiary structure of the proteins. The disulfide bonds also contribute to the secondary and quaternary structures of the proteins.

(c) Role of $-\mathrm{SH}$ in one carbon metabolism. The thiol group of homocysteine provides the site for $-\mathrm{CH}_{3}$ group and thereby actively take part in one carbon metabolism. When hydrogen atom of the $-\mathrm{SH}$ of homocysteine is replaced by $-\mathrm{CH}_{3}$ group, the new compound formed by this replacement is methionine, 
an essential amino acid. Methionine transfers the $-\mathrm{CH}_{3}$ group with the active participation of vitamin $\mathrm{B}_{12}$ to synthesize various metabolites which include thymine, a base for DNA, creatine, choline and lecithin, a phospholipid.

(d) The $-\mathrm{SH}$ in synthesis of bio-reductants. The TAA, cysteine takes part in the synthesis of bio-reductants like glutathiome, and reduced $\mathrm{C}_{\mathrm{O}} \mathrm{A}\left(\mathrm{C}_{\mathrm{O}} \mathrm{A}-\mathrm{SH}\right)$. They also take part in a large number of biological oxidation-reduction reactions.

Importance of TAA in Foods

Flavor, color and texture are characteristics of foods that to a large extent determine its acceptability. TAA contributes to these characteristics in many foods.

TAA as flavor enhancer. Hydrogen sulfide; methyl, ethyl, propyl, and butyl mercaptans; and dimethyl sulfide and disulfide are constituents of beef flavor [Herz and Change, 1970]. Poultry flavor contains hydrogen sulfide; methyl, ethyl, propyl and hexyl mercaptans; dimethyl, methyl ethyl, diethyl, methylisopropyl and dipropyl sulfides and methyl disulfide [Minor, et al., 1965B]. Cystine and cysteine residues in muscle protein are the chief precursors in meat flavor and are the chief precursors of $\mathrm{H}_{2} \mathrm{~S}$ in chicken flavor [Mecchi, et al., 1964]. The flavor of boiled milk, in part, is due to volatile sulfides and hydrogen sulfide in particular [Jenness and Patton, 1952]. The flavor of fresh cooked fish is also partially due to hydrogen sulfide, mercaptans 
and organic sulfides [Hughes, 1964A]. Similar flavoring agents are found in hard boiled eggs.

TAA as flavor reductant. The thiol groups produce hydrogen sulfide on reduction. Excessive production of hydrogen sulfide also reduces flavor as in rotten eggs and spoiled fish. The presence of hydrogen sulfide in fish is indicative of spoilage [Merritt and Mendelsohn, 1962].

The role of thiol amino acids in food color. The brightness or color of a food is indicative of its freshness while dullness or loss of color is due to spoilage or other changes. Thiol groups of proteins are responsible for both desirable and undesirable colors in foods. The greenish color in the yolk of hard boiled eggs is not undesirable, but black or bluish coloration of canned tuna is not desirable. Similarly, the blackening of some canned products, or any kind of discoloration, is undesirable. Most of these color changes or discoloration, as the case may be, are attributed to the reactions of degradation products of protein TAA with iron present in the foods, or derived from the containers in which they were preserved.

The addition of cysteine prevents browning of whole egg or egg-white during drying [Lightbody and Favold, 1948]. This is due to the formation of colorless thiazolidinecarboxylic acid resulting from the reaction of cysteine and glucose. 
TAA and functional properties of foods. It has been postulated that a continuous reaction between intermolecular disulfides and thiols is desirable in dough making [Sullivan, 1954], thereby (1) strengthening the gluten of wheat flour, (2) increasing the elasticity of the dough and (3) improving the water absorption. A reaction diagram of what may happen in dough making has been shown by Meridith [1969] as shown below:

$$
\text { Disulfides } \rightleftharpoons \text { sulphydryl group }
$$

There is an increase in the -SH groups in heat denatured proteins [Desrosier, 1963] such as egg albumin.

The -SH groups in egg albumin increases on heating with a loss of solubility in water. The heat denaturation unfolds the peptide chains, probably debars the interaction of $-\mathrm{SH}$ and -SS- groups and thereby reduces the solubility of egg albumin.

Effects of processing on thiols of proteins. The protein foods are presently processed in various ways, namely freezing, freeze-drying, canning, drying, salting, pickling, and curing. All these methods of processing and preservation are used for fish in various parts of the world. About onethird of the total catch of aquatic animals are converted into fish meal and oil [Barlow and Burton, 1973]. Considerable thermal energy is used in the production of fish meal and FPC. So, the effect of thermal energy on -SH and -SS- groups of proteins will be reviewed. 
The thermal processing, which also includes cooking, of protein food, causes the appearance of hydrogen sulfide and their derivates already mentioned. The sulfur amino acids are the precursors of hydrogen sulfide and its derivatives. The splitting of the -SS- bonds in proteins usually occurs more rapidly under alkaline conditions [Feeny and Hill, 1960]. Beef [Herz and Chang, 1970], egg [Ammerman, 1957], fish [Dunn, et al., 1949 and Neiland, et al., 1947], pork [Beuk, et al., 1948] and poultry [Mecchi, et al., 1964 and Minor, et al., 1965B], release significant amounts of hydrogen sulfide and its deriviatives at the cost of SAA during cooking.

Nutritional aspect of TAA. The fundamental studies of Osborme and Mendel [1914] led to a realization that the nutritive value of proteins is dependent upon their content of amino acids required for growth, maintenance and other metabolic functions. Eight to twelve of the twenty-two or more amino acids in proteins are essential to animals depending on the species and on their respective physiological states. The following eight amino acids are essential for maintenance in adult human subjects: lysine, methionine, valine, leucine, isoleucine, threonine, phenylalanine and tryptophan [Rose, et al., 1955]. Certain non-essential amino acids can spare the requirement for essential amino acid. For example, cystine can spare 80-90 per cent of methionine requirement of man [Rose and Wixome, 1955]. Two 
moles of cysteine can replace one mole of cystine. The amino acids essential for adult humans are also essential for the dog, cat, and chicken [Rice and Beuk, 1953].

As early as the 1940's it was shown that, with the exception of lysine, the amino acid requirement of an adult human can be met by the normal intake of grains [Block and Boiling, 1944]. Most animal proteins, including fish protein, are good sources of this amino acid and the SAA [Block, 1945]. Corm, oat, cottonseed, peanut and soybean meals are low in methionine [Block, 1945; Soares and Kifer, 1971 and Sasse and Baker, 1973]. Fish meal is used as a supplemental protein to compensate for nutritional deficiencies that would arise if only grain products were fed to animals [Grau and Williams, 1955 and Miller and Kifer, 1970].

Attempts have been made to quantify the requirements of SAA in rats [Stockland, et al., 1973], broilers [Dean and Scott, 1965], and laying hens [Harmes and Damron, 1969]. The requirements of different amino acids in various domesticated and laboratory animals have been listed [NAS, 1968, 1971, 1972].

\section{Review on Methodology of Determining TAA.}

A number of methods of determining TAA in proteins are dependent on the availability of the functional -SH groups. The -SS- groups must be reduced to -SH groups before determination by most methods. The procedures used for the determination of TAA may be divided into three main groups, e.g., 
(1) titrimetric, (2) spectrophotometric, and (3) miscellaneous.

\section{(1) Titrimetric methods}

These methods may be subdivided into (a) colorimetric titration and (b) electrometric titration.

(a) Colorimetric titration. (i) 0-iodosobenzoate (or O-iodosobenzoic acid) oxidizes -SH to -SS- releasing an equivalent amount of iodine which is titrated with standard sodium thiosulfate solution to the colorless end point from its blue starch complex [Hellerman, et al., 1941 and Hellerman, et al., 1943]. The -SS- can be determined by the same procedure after its reduction to thiol. The difference between the $-\mathrm{SH}$ contents before and after reduction of the sample will give the amounts of -SS- present in the sample.

(ii) Porphyrindin has been used in assaying - SH in biological substances [Balls and Lineweaver, 1939]. Appearance of the color of porphyrindin in the titration solution indicates the end point of the titration.

$\mathrm{RSH}+$ Porphyrindin $\rightarrow$ R-SS-R + leucoporphyrindin The -SS- content also can be determined after its reduction to $-\mathrm{SH}$.

(iii) Sodium tetrathionate oxidizes -SH to the -SSbeing itself reduced to sodium thiosulfate [Gilman, et al., 1946]. The amount of sodium thiosulfate produced by oxidation of $-\mathrm{SH}$ can be titrated quantitatively by standard iodine solution using starch as an indicator. Similarly, as mentioned before, the -SS- groups can also be determined after 
their reduction to $-\mathrm{SH}$.

(b) Electrometric titrations. In the electrometric titrations, the end point can be detected (i) amperometrically, by the sharp change in the flow of current at constant voltage; or (ii) potentiometrically, by the sharp change in potential of the titration system; or (iii) polarographically, by the intensity of a current flowing through the analyzed solution on its voltage

(i) Amperometric titration. The amount of current passing through the cell at constant voltage is measured and plotted against the volume of standardized reagent added, generally, using a rotating platinum electrode or a dropping mercury electrode. This method is essentially based on a mercaptide forming reaction as per equation:

$$
\mathrm{R}-\mathrm{SH}+\mathrm{M}^{+} \longrightarrow \mathrm{R}-\mathrm{SM}+\mathrm{H}^{+}
$$

$\mathrm{M}^{+}$normally represents soluble inorganic silver [Burton, 1958; Sluyterman, 1957 and 1966; Kolthoff and Eisenstadter, 1961], or mercury as salts [Ingram, 1955; Kolthoff and Willeford, 1947; Taso and Bailey, 1953], and an organic mercury compound such as p-chloromercuribenzoate-PCMB [Benesch and Benesch, 1948]. O-iodosobenzoic acid or its soluble salt has also been used as a titrant [Larson and Jenness, 1950].

(ii) Potentiometric titration. In this method, change of potential is noted after each addition of titrant and plotted against the volume of titrant. The equivalence point is noted from the plot where maximum change in potential is observed after a single addition of titrant. This method is 
actually based on the Nemst equation:

where

$$
E=E a+2.3 \frac{R T}{n F} \log A x \pm
$$

$\mathrm{E} \quad=$ measured potential of the system

$\mathrm{Ea}$ = the portion of total potential due to reference electrode and internal solutions

2.3 $\frac{\mathrm{RT}}{\mathrm{nF}}=$ Nermst factor $(59.1 / \mathrm{n} \mathrm{mV}$ at $25 \mathrm{C}) ; \mathrm{R}$ and $\mathrm{F}$ are constants, is the charge on the ion and $T$ is temperature in degrees Kelvin $\mathrm{Ax} \pm$ = The activity of the ion element in solution and \pm denotes, if the charge on ion is + ve or - ve. The specific-ion electrode along with a reference electrode and a sensitive galvanometer are generally used for this type of titration. Various kinds of electrodes [Willard, 1969] are in use. An excellent review work on the specific-ion electrodes has been published by Durst [1969].

$\mathrm{A} \mathrm{Ag} / \mathrm{S}$ specific-ion electrode has been successfully used in determining sulfide [Bock and Puff, 1968 and Nauman and Weber, 1971]; silver [Muller, et al., 1969 and Fletcher and Mannion, 1970]; $\mathrm{H}_{2} \mathrm{~S}$ [Gruenwedel and Patnaik, 1971]; thiol [Gruen and Harrap, 1971], and disulfide [Harrap and Gruen, 1971]. The double junction $\mathrm{Ag} / \mathrm{AgCl}$ electrode has been suggested for use as a reference electrode by Orion Research Inc. [1972].

(iii) Polarography. This is another electrometric method for determining -SH. This procedure has been reviewed by Homolka [1971]. In the polarographic method, voltage and 
current in the test solution are constantly increased. The changes in voltage and current are recorded and compared with a curve prepared for standard solution of thiols and disulfides.

In polargraphic analysis of proteins, a solution of cobaltic hexaminochloride is preferred to a cobaltous chloride solution to overcome the overlapping of cystine and cysteine which may also be present in the solution.

(iv) Spectrophotometric determination of TAA. Infrared, ultra-violet and visual regions of spectra are in use to identify the presence of and to determine quantitatively the thiol groups directly and/or indirectly.

(a) Infrared analysis of TAA. The thiol groups can be identified by hydrogenic stretching in the frequency between $3.85-4.0 \mu$. But by hydrogen bonding, the frequency may be changed to $3.9-4.05 \mu$ [Sutherland, 1952].

This procedure is not used in routine quantitative analysis.

(b) Ultra-violet (U.V.) spectroscopy of TAA. It has been reported that cysteine absorbs strongly in $0.1 \mathrm{~N}$ acid at $230 \mathrm{~nm}$ [Fromageot, and Schneck, 1950]. Cystine absorbs in alkali at $245 \mathrm{~nm}$ and shifts to $240 \mathrm{~nm}$ in acid solution [Framageot and Schneck, 1950].

The peptide, reduced glutathione (GSH) after irridation, showed absorption maximum at $325 \mathrm{~nm}$ for $-\mathrm{SH}$ and at $251 \mathrm{~nm}$ for -SS- [Anslow and Lyman, 1941]. These are not 
widely used methods for determining -SH and -SS- in proteins or other complex solutions.

(c) Visual region spectrophotometry or colorimetric determination of thiols. Numerous methods of determining -SH groups have been developed on the basis of absorption in the visual region of the spectrum. Some of them are described below:

(i) p-chloromecuribenzoate (PCMB) is allowed to react in aqueous solution containing the thiol group. After reaction, the excess reagent, $\mathrm{PCMB}$, is extracted with $\mathrm{CCl}_{4}$ solution of dithizone and the decrease in the free dithizone concentration is measured spectrophotometrically at $650 \mathrm{~nm}$ [Fridovice and Handler, 1957].

(ii) Sullivan and Associates [1942] have developed a colorimetric method for qualitative determination of cysteine in protein hydrolyzates. When cysteine is treated with sodium 1,2 - naphthoquinone - 4 sulfonate in alkaline solution in the presence of a strong reducing agent such as sodium hyposulfite, a red color is produced and the color is compared with the color produced by standard cysteine solutions.

(iii) Sodium nitroprusside gives a color reaction with thiol which absorbs strongly at $546 \mathrm{~nm}$ [Lyman, 1951].

(iv) Column chromatography has been used in conjunction with colorimetry as a method for determining the amino acid composition of a protein hydrosolyzate. Several different versions of this instrumentation are available. One of these, amino acid autoanalyzer has been used in our work. Two sets 
of colorimeters are needed to determine amino acids at $570 \mathrm{~nm}$ and imino acids at $440 \mathrm{~nm}$ using ninhydrin as the color reagent.

Miscellaneous Method for Determination of TAA in Proteins

The combined cystine and cysteine content in proteins can be determined quantitatively as cysteic acid [Moore, 1963]. The method is essentially the combination of oxidation of -SH and -SS- groups in the proteins with performic acid, separation of cysteic acid by column chromatography after acid hydrolysis of the proteins and determination of cysteic acid colorimetrically at $570 \mathrm{~nm}$ using ninhydrin reagent. 


\section{III}

MATERIALS AND METHODS

\section{Materials}

\section{Fish and Fish Products}

Two commercially important species, herring (Clupea harengus) and menhaden (Brevoortia tyrannus) were used in the studies. One lot of each species were received in fresh condition from the Roint Judith Fisherman's Co-operative, Point Judith, Rhode Island.

In addition, menhaden press-cake was collected and processed. Commercially produced menhaden fish meal was used as a reference standard fish meal. Both the press-cake and fish meal produced from menhaden were received from Lipman Marine Inc., State Pier, Gloucester, Massachusetts. The press-cake was brought to the laboratory after preserving in methanol to prevent spoilage before processing.

The Experimental Animals

Unsexed, 7-day old White Rock chicks were used in determining the effects of various fish protein supplements on growth and feed conversion. Feeding studies were conducted in modified Petersine incubators which were housed at the University of Rhode Island East Farm Nutrition Laboratory.

(a) The counter current azeotropic distillation system The counter current azeotropic distillation system 
consisted of a solvent and steam supply lines, a pre-heater with a solvent gauge, a heat exchanger with a thermometer, a six-stage counter current distillation column fitted with a stirrer and a screw conveyor. The column was also connected with a fish slurry feed line, miscella and azeotropic vapor discharge lines. A condenser and a fish slurry tank were integral parts of the system.

The solvent supply lines consisted of supply tank and the line connected to the bottom of the solvent pre-heater. The pre-heater was $120 \mathrm{~cm}$ in height. It was connected with the live steam line and a $120 \mathrm{~cm}$ vertical pipe line which was connected at the bottom with the pre-heater having a valve in between them and a solvent gauge. The solvent gauge was fitted to the pipe line to indicate the level of the solvent in the pre-heater and to control the flow of the solvent into it. The other end of the pipe line was connected to the heat exchanger. The heat exchanger was connected to the distillation column at the bottom. There was a valve between the column and the heat exchanger to control the passage of vapor into the column.

A thermometer was fitted at the bottom end of the heat exchanger to indicate the temperature of the vapor entering the distillation column.

The distillation column was made of pyrex glass. It was $11.5 \mathrm{~cm}$ in diameter (outer diameter) and $135 \mathrm{~cm}$ in height. The column consisted of seven glass cylinders of which six were $16 \mathrm{~cm} \times 11.5 \mathrm{~cm}$ and one section was $35 \mathrm{~cm}$ in 
length $x 11.5 \mathrm{~cm}$ in diameter. Each of them, except the bottom one, was clamped end to end with a perforated metal plate having a central hole and two other holes $(2.5 \mathrm{~cm}$ in diameter) situated diagonally opposite to each other, and teflon coated gaskets in between the metal plate and the glass cylinders. The bottom one was fixed on a platform with proper sealing with teflon coated gasket. Those made six chambers in the distillation column. At the bottom of the column, a screw conveyor was fitted. A stirrer was fitted through the central holes of the plates. The stirrer had one pair of blades close to the perforated plates in each chamber to drive the fish particles to the next lower chamber by gravity, and another pair of blades was fitted at about the middle of each chamber to keep the fish particles moving. The fish slurry was fed into the column at the height of $95 \mathrm{~cm}$ from the base of the column. The miscella discharge line was at the height of $120 \mathrm{~cm}$. The azeotropic vapor discharge line was connected at the top of the column. The vapor line was connected with the condenser to condense the azeotropic vapor in the latter. The condenser was connected with cold water supply line. The fish slurry tank was a cast iron cylinder with a cone at the bottom. It had an opening ( $8 \mathrm{~cm}$ in diameter) at the top. The opening could be closed tightly by a threaded cap. There was a pressure gauge fitted at the top of the slurry tank to measure the pressure of the air inside the tank. In addition, it was connected with a high pressure air line. A pressure-hose of $5 \mathrm{~cm}$ (I.D.) connected at the bottom 
of the fish slurry tank and the distillation column was used as the fish slurry delivery line to the column.

(b) The batch azeotropic distillation system The batch azeotropic distillation system consisted of a stainless steel reactor with a capacity of 13.5 liters, a glass cover with three openings suitable for ground glass fittings, a glass column, a condenser fitted with cold water circulating system and a one-liter stoppered glass funnel with a ground glass fitting. The size of the ground glass joints

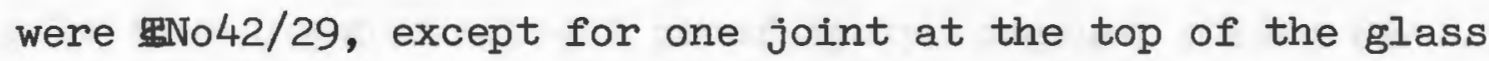
column which had a joint mNo.10/30 to fit a thermometer. The thermometer was used to record the temperature of the azeotropic vapor. In addition, there was an electric heater suitable to hold the reactor and an electrically operated stirrer and a tele-thermometer (YSI model 42SC).

The reactor was placed upright on the electric heater. The flow of current was controlled using two power-stats. The top of the reactor was tightly closed with the glass cover having three openings by means of a clamp. The electric stirrer was connected through the middle opening of the cover. The glass column was fitted into the second opening. The thermometer was fitted at top of the column. The column was connected to the condenser with joints. The condenser was hooked up to the cold water circulating system. The stoppered funnel was fitted into the third opening of the glass cover. 
Ionalyzer and Specific-ion Electrode

The ionalyzer, a specific-ion meter (model 407), a silver/sulfide specific-ion electrode (model 94-16) and a double junction reference electrode (model 90-02), all from Orion Research, Inc., Cambridge, Massachusetts, were used in measuring the potential differences developed during -SH titration.

In the $\mathrm{Ag} / \mathrm{S}$ ion electrode, a metallic silver wire coated with highly insoluble $\mathrm{Ag}_{2} \mathrm{~S}$ is attached to a fused Ag2S disc. This whole system is housed in acid, alkali and some selective organic solvent proof epoxy compound (Orion Research, Inc., 1972). The reference electrode was a hollow $\mathrm{Ag} / \mathrm{AgCl}$ tube which acts as inner filling chamber and it was connected with a silver spring from the cap. The inner chamber was housed in an unbreakable plastic chamber (outer chamber) which was said to be acid, alkali and solvent resistant. The filling solution of the inner chamber was KCl solution and the filling solution for the outer chamber was $\mathrm{KNO}_{3}$ (10\%) solution.

The specific-ion meter could be used to measure \pm $1000 \mathrm{mV}$. Each division on the scale was equivalent to $20 \mathrm{mV}$ with the switch at the $\mathrm{mV}$ position on the meter.

(d) Amino acid autoanalyzer

An amino acid autoanalyzer manufactured by Technicon Corporation, located in the "Dairy Barm Laboratory" of the Department of Animal Science at the University of Rhode Island, was used to determine the amino acid composition of the fish 
products with the exception of the amino acids tryptophan and proline.

\section{(e) Stirrer incubator}

A thermostatically controlled magnetic stirrer incubator (model 770) from Eberbach Corporation, Ann Arbor, Michigan, was used in enzymatic hydrolysis of fish products.

\section{Solvents}

A commercial grade of methanol was used to dehydrate, partially extract lipids and to preserve the fresh ground fish and press-cake. Commercial grade hydrocarbons, heptane and hexane, were used in azeotropic distillation of methanol from fish cake and for simultaneous extraction of lipids from the products.

\section{Chemicals and Biochemicals}

The chemicals used in this research were obtained from the following suppliers or manufacturers:

Crystalline pepsin

Subtilisin BPN'

Cysteine (free base)

Cysteine hydrochloride

Cystine (free base)

Silver nitrate

Glutathione

Sodium borohydride $\left(\mathrm{NaBH}_{4}\right)$

Urea

Tris (hydroxymethyl)

amino methane
Merck and Company

Sigma Chemical Company

Nutritional Biochemical Corp. Nutritional Biochemical Corp. Nutritional Biochemical Corp. Fisher Scientific Corp. Fisher Scientific Corp. Fisher Scientific Corp. Fisher Scientific Corp. Commercial Solvents 
Imidazole

Hydrazine sulfate

Ninhydrin

Methyl cellosolve

Nor-leucine

Standard amino acid solution
Eastman Kodak Company

Eastman Kodak Company

Pierce Chemical Company

Pierce Chemical Company

Pierce Chemical Company

Pierce Chemical Company

\section{Methods}

Method of Processing Fish and Press-Cake

Ground fish, herring and menhaden, as well as the press-cake of the latter species were processed by the azeotropic distillation method of Meade [1973]. The process was developed to produce low fat content fish meal from presscake produced by conventional wet reduction. The process has been summarized in the patent literature and is quoted for general information.

Thus, the present invention provides a process for preserving and dehydrating fish press-cake, which comprises: ( 1 ) adding an alcohol to water--containing fish press-cake; (2) storing the press-cake-wateralcohol mixture of step (1) in a preserved state; and subsequently (3) removing water and alcohol from the press-cake-water-alcohol mixture of step (2) by adding a hydrocarbon to said mixture and extracting an azeotropic vapor comprising the alcohol and hydrocarbon followed by azeotropic vapor comprising water and hydrocarbon. If desired, the azeotropic extraction step of the invention can be utilized per se to remove alcohol from any alcohol and water-containing presscake mixture. This unique extraction allows the substantially complete removal of alcohol in a single stage whereas conventional azeotropic extraction of simply water and alcohol from such mixtures theoretically requires an indefinite number of stages for complete alcohol removal. 
In any event, utilization of the above process in combination with a conventional wet reduction process for obtaining fish meal allows the cooking and pressing operation to be carried out in direct relation to supply of raw fish (landing) and yet, because of the ability to preserve fish press-cake, the final defatting and/or dehydration step can be suspended from time to time and performed only when the accumulation of press-cake matches installed processing capacity.

The above mentioned principle of azeotropic distillation was used in preparing the fish products with a slight modification for fresh and frozen fish. Instead of cooking fish to obtain the press-cake, the following procedure was adopted:

Each fish was washed with tap water to get rid of as much dirt and slime as possible. About half the amount of fish of each lot of herring and menhaden was kept frozen for future use. Both species were ground separately in a power driven "Hobart Meat Grinder," using perforated disc with 0.96 and $0.64 \mathrm{~cm}$ diameter holes successively. The whole fish was ground. The ground fish was mixed with an equal amount of commercial grade of methanol ( $1: 1 \mathrm{wt} / \mathrm{wt}$ ) at room temperature. The miscella was tapped off and the thick, wet-fish-methanolcake was pressed mechanically in a hand-operated press to squeeze out as much miscella as possible. The press-cake thus obtained and the cake received from Lipman Marine Inc. were mixed with fresh methanol [ground fish to methanol: I:I wt/wt)] separately and kept preserved until used to make the final product by azeotropic method. Either heptane or hexane was used as hydrocarbon for the distillation and extraction purposes. 
The menhaden press-cake received from Lipman Marine Inc. were produced by conventional method of cooking whole fish and pressing the cooked fish to press-cake. The menhaden meal was produced by drying and disintegrating the dried cake to meal.

\section{Analytical Methods}

The composition of raw ground, fish and the fish products for protein, lipid, total volatiles (T.V.), ash, pepsin digestibility and peroxide value of oxidized products was determined by the following methods:

Protein - Protein was determined by Macro-Kjeldahl method of the AOAC [1970, Section 7.016].

T.V. - T.V. was determined by the AOAC method [1970, Section 24.003].

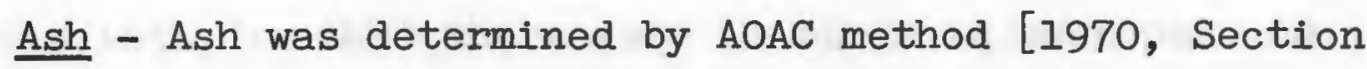
18.012].

Peroxide value - The peroxide value was determined by the AOCS method [1964, ed. 8, p. 53].

Amino Acids - The amino acid content was determined following the "Instruction Manual for Amino Acid Autoanalyzer" of Technicon Corporation [1967].

Cysteine - Cysteine in fish protein hydrolyzates was determined by the method of Gruen and Harrap [1971].

$1 / 2$ Cystine - 1/2 cystine in fish protein hydrolyzates from fish products was determined by the method of Harrap and Gruen [1971]. 
Pepsin digestibility - Pepsin digestibility was determined by the AOAC method [1970, Section 7.045].

\section{Bio Assay of Fish Proteins}

The evaluation of the nutritional quality of proteins - of different fish products produced in the laboratory was carried out with a 10-day feeding test, which is similar to the method developed by Bird, et al. [1965], except for the time.

The chicks were fed for one week on "Blue Seal" starter ration manufactured by H.K. Webster Co., Inc., Lawrence, Massachusetts. After one week, the chicks were weighed and grouped in $5 \mathrm{gm}$ lots. The chicks of the middle weight lots were distributed starting from the selected lowest-weight lot to the highest-weight lot through the successive lots, so that there were 10 birds in each pen and the weights of the birds in each pen were similar. There were three replicates for each diet. One hundred fifty chicks were used in each experiment. They were fed control and experimental diets ad libitum, and were maintained in Petersine incubators where all environmental factors were equalized. Clean, cool water was available at all times. The weight gain per bird and feed conversion were calculated. 


\section{EXPERIMENTAL}

The experimental part of this study is divided into three sections: (A) The preparation of fish products (FP); (B) The evaluation of their respective nutritive value by bio-assay technique using chicks'as the test animal, and (C) The development of a method for determining the thiol amino acids of the fish products using $\mathrm{Ag} / \mathrm{S}$ specific-ion electrode.

\section{A. The Preparation of FP}

This section is sub-divided into two sub-sections: (a) The preliminary experimentation in fish products preparation and (b) The selection of the methods and preparation of FP for feeding tests with different levels of TAA in the FP。

(a) The preliminary experimentation in fish products preparation

The object of conducting preliminary experiments to prepare FP was to select suitable methods for producing FP with different levels of TAA. At the same time, the selected methods were consistent with the accepted methods of manufacturing FP, e.g., fish meal and FPC, with necessary modifications where they might be required. The need of modification in the existing methods were judged by 
analyzing the FP for protein, moisture (T.V.), lipids, ash, amino acids content and pepsin digestibility. The FP were prepared by the following methods using press-cake made after dehydrating ground fish with methanol.

(i) Preparation of FP by simultaneous counter current Azeotropic distillation and extraction method

Three kilograms of press-cake, produced as described above, were mixed with $3 \mathrm{~kg}$ of heptane tó make a slurry. The slurry was poured into the fish slurry tank and the feeding neck was tightly closed with the threaded cap. A portion of the slurry was drawn into the extraction column at a pressure between 4 and 5 psi using compressed air. Simultaneously, the solvent, heptane, was pumped into the pre-heater and was evaporated there. The vapor was passed continuously into the bottom of the distillation column by the pressure of the solvent vapor through the heat-exchanger, at a certain rate to provide heat to column materials, to distill out methanol at the first stage, and water at the later stage azeotropically, and extract lipids from fish. Methanol form an azeotrope with heptane at $59.1 \mathrm{C}$ (59-61 C in the case of the commercial methanol and heptane) with $51 \%$ methanol by volume. Water forms an azeotrope with heptane at $80 \mathrm{C}$ with $9 \% \mathrm{H}_{2} \mathrm{O}$ by volume. When the temperature within the distillation column and the percentage composition of water and heptane of the condensate indicated the completion of the removal of methanol, the FP was taken out of the column using a screw conveyor. 
Another batch of slurry was immediately drawn into the column. This was continued until the whole slurry was converted to FP. Two samples, $\mathrm{FP}_{1}$ and $\mathrm{FP}_{2}$ were produced in that way.

(ii) Preparation of high oil content FP at ambient temperature by cocurrent solvent extraction method

The frozen herring was partially thawed and ground. One $\mathrm{kg}$ of ground fish was cocurrently, extracted with $1 \mathrm{~kg}$ of methanol twice for a period of 20 minutes each time with constant stirring. The miscella was removed by pressing with a hand-operated press after each extraction. The press-cake was desolventized in air. The product was $\mathrm{FP}_{3}$.

(iii) Preparation of low fat content FP at room temperature by cocurrent solvent extraction method

The frozen herring was partially thawed and ground. One $\mathrm{kg}$ of ground fish was cocurrently extracted with $1 \mathrm{~kg}$ of methanol twice. The period of extraction was 20 minutes each time. It was continuously stirred and the experiment was conducted at room temperature. The miscella was pressed out after each extraction using a hand-operated press. The press-cake was extracted cocurrently three times using $1 \mathrm{~kg}$ of heptane each time for 20 minutes at ambient temperature. The miscella was separated each time by pressing. The extracted ground fish was desolventized in air to $\mathrm{FP}_{4}$.

(iv) The prepration of FP with high oil content at high temperature

The frozen herring was partially thawed and ground. One $\mathrm{kg}$ of ground fish was dried at $95 \pm 5 \mathrm{C}$ for 18 hours in an air oven. Half of the product was used as FP5 with high 
oil content prepared at high temperature.

(v) The preparation of FP with low fat content at high temperature

The second half of the oven dried fish was extracted cocurrently twice with 500 gm of methanol and three times with $500 \mathrm{~g}$ of heptane each time, at room temperature. The period of extraction was 20 minutes each time. The miscella was filtered out using an aspirator each time. The product $\left(\mathrm{FP}_{6}\right.$ ) was desolventized in air.

The protein, T.V., lipids and ash composition of fresh ground herring and menhaden are shown in Table 1. The composition of fish products $\mathrm{FP}_{1}$ through $\mathrm{FP} 6$, are shown in Table 2. The amino acids composition, except tryptophan, was determined by the amino acid autoanalyzer (AAA) method. The results are shown in Table 3. It was noted that the FP produced at high temperature with high or low fat content, and the FP prepared at low temperature with high fat content, retained less TAA than those FP prepared by simultaneous azeotropic distillation and extraction methods or by the cocurrent solvent extraction method at room temperature.

(b) The selection of methods and preparation of FP for feeding tests

Reviewing the results of TAA contents in FPs prepared in the preliminary experiments, it was decided to prepare two FP from herring, one $\left(\mathrm{FP}_{7}\right)$ with a high level of TAA produced by batch azeotropic distillation along with solvent extraction method using heptane as solvent and fish cake 
obtained after dehydrating ground fresh fish with methanol at room temperature. The second product $\left(\mathrm{FP}_{8}\right)$ was prepared by dehydrating the ground fish by two extractions with methanol. The cake was autoxidized in air for 5 weeks to reduce the TAA contents. After 5 weeks, the autoxidized lipids and residual alcohol were removed by azeotropic distillation followed by solvent extraction. In addition, it was decided to prepare one sample (FPg) from fresh menhaden following the procedure used to make $\mathrm{FP}_{7}$ and another sample, $\mathrm{FP}_{10}$, from menhaden press-cake, prepared by the conventional wet reduction method of manufacturing menhaden meal, by azeotropic method. The menhaden meal $\left(F P_{11}\right)$ was used as a control fish product.

(i) Preparation of high TAA fish product $\left(\mathrm{FP}_{7}\right)$ from herring

Twenty-three $\mathrm{kg}$ of frozen herring was partially thawed, ground and partially dehydrated using $23 \mathrm{~kg}$ of methanol. The partially dehydrated ground fish was further dehydrated using another portion of $23 \mathrm{~kg}$ of methanol and kept preserved until it was finally processed.

One-half of the above mentioned preserved ground fish was converted to press-cake by removing methanol-water-oil miscella mechancially by a hand-operated press. The press-cake was processed to a high TAA fish product by batch azeotropic solvent extraction method using heptane as solvent. The extracted mass was washed twice with $10 \mathrm{~kg}$ of heptane. The wet cake was desolventized in air to $\mathrm{FP}_{7}$. 

(ii) Preparation of low TAA fish product $\left(\mathrm{FP}_{8}\right)$ from
herring

The remaining one-half of the ground fish preserved in methanol was converted to cake by removing the methanol-wateroil miscella by decanting the miscella and pressing the wet mass in a hand-operated press. The cake was subjected to autoxidation in air for five weeks. The level of oxidation was checked every week and was reportẹ as peroxide number. The consumption of standard $\mathrm{AgNO}_{3}$ solution by the hydrolyzates of fish products ( $50 \mathrm{mg}$ ) was also noted each week. The hydrolyzates were prepared in imidazole buffer ( $0.1 \mathrm{M}$ ) at $\mathrm{pH} 7$ and at a temperature of $37 \mathrm{C}$ with $1 \mathrm{ml}$ of $1.0 \mathrm{mg} / \mathrm{ml}$ subtilisin BPN' solution in distilled water. The period of hydrolysis was 18 hours. The fish products used in hydrolysis were prepared each week by removing fat from $50 \mathrm{~g}$ of cake using $100 \mathrm{ml}$ of heptane each time. Each product was extracted three times. The peroxide number and the corresponding value of $1 / 2$ cystine (\%) for each week are tabulated in Table 4.

After autoxidizing the cake for five weeks, it was subjected to azeotropic distillation using heptane to remove methanol. The miscella was removed by pressing. The cake was washed twice with $10 \mathrm{~kg}$ of heptane each time to reduce the level of fat. The wet cake was desolventized in air to obtain FP8.

(iii) Preparation of fish product with high TAA level (FP9) from menhaden

Ten $\mathrm{kg}$ of fresh menhaden was ground and converted to 
press-cake by dehydrating ground fish with $10 \mathrm{~kg}$ of methanol twice. Methanol was removed by azeotropic distillation and solvent extraction method using heptane. The extracted cake was washed twice with $10 \mathrm{~kg}$ of heptane each time to lower the level of fats. The wet cake was desolventized in air to obtain $\mathrm{FP}_{9}$.

(iv) Preparation of fish product $\left(\mathrm{FP}_{10}\right.$ ) from menhaden press-cake prepared by wet reduction method

The menhaden press-cake was preserved in methanol and brought to the laboratory. The methanol miscella was removed by pressing. The cake was again mixed with methanol, with the ratio of cake to alcohol at $1: 1.66$ and held overmight. Next day the miscella was removed, the wet mass was pressed to remove more miscella and the methanol was removed by batch azeotropic distillation method using hexane as the azeotrope former in place of heptane. The extracted cake was washed twice with hexane with a ratio of cake to solvent of $1: 1.5$ $\mathrm{wt} / \mathrm{wt}$ to lower the level of fat. The washed cake was desolventized in air to $\mathrm{FP}_{10}$.

The commercial menhaden meal used was produced by the wet reduction method and designated $\mathrm{FP}_{11}$. This meal was used as the control in the feeding tests carried out in the biological assay part of the study.

The fish products FP7-FPII were analyzed for protein, T.V., fat, ash and pepsin digestibility and are presented in Table 2. The amino acid profile, except trypotophan and proline, of each product, was determined and is given in 
Table 3. Determinations were carried out by the AAA method.

B. Evaluation of Nutritional Quality of Fish Products

( $\left.\underline{F P}_{7}-\underline{F P}_{11}\right)$ by Chick Bio-Assay Technique

The fish products $\mathrm{FP}_{7}-\mathrm{FP}_{11}$ were evaluated for nutritional quality by chick feeding tests. Two levels of protein were used in the feeding tests: (a) Experimental diet (21\% protein) and (b) Experimental dièt (18\% protein). Both types of rations were supplemented with ample vitamins and minerals. The energy level was similar in both diets.

(a) Evaluation of nutritional quality of "Experimental diet (2l\% protein)" supplemented with fish products $\left.\mathrm{FP}_{7}-\mathrm{FP}_{11}\right)$

Five rations were formulated using five different fish products to supplement the essential amino acids in the diets made with soybean oil meal (SBOM), ground yellow corn meal (GYCM), alfalfa meal, yellow fat, dical phosphate, vitamin mixture, trace element mixture (Table 5). The composition of vitamin mixture and trace element mixture used are reported in Table 7. The diets were mixed mechanically.

Two hundred chicks were placed on a "starter ration" immediately after they had been hatched out. After one week, the chicks were sorted out to $5 \mathrm{~g}$ weight lots. The chicks of middle weight lots were distributed in 15 pens with 10 birds in each pen. The method of distribution of chicks in pens is shown in Table 8. The chicks in three pens were allowed to eat ad libitum with one type of diet. Plenty of water was provided and they were kept in an identical 
environment in all 15 pens. After 10 days, the chicks in each pen were weighed and the total amount of feed consumed in each ration was recorded. The average weight gain per bird and the average feed consumed per bird per day were calculated. The ratio of feed consumed (F) and the weight gained per bird (G) for each ration was calculated using the following formula:

$$
F / G=\frac{\text { The average feed consumed per bird per day }}{\text { The average weight gained per bird per day }}
$$

The F/G for the rations are tabulated in Table 10-a.

(b) Evaluation of nutritional quality of rations with "Experimental diet ( $18 \%$ protein)" supplemented with fish products $\mathrm{FP}_{7}-\mathrm{FP}_{11}$

Five rations were formulated restricting the level of protein to $18.0 \%$ by reducing the level of SBOM and increasing the quantity of GYCM. The levels of fish products, alfalfa meal, vitamins and mineral mixtures were kept unaltered from the previous rations. The level of yellow fat was changed slightly. The feed formulation data are given in Table 6.

Two hundred chicks were placed on a "starter ration" as before for seven days. After seven days, the chicks were grouped in $5 \mathrm{~g}$ weight lots. One hundred fifty birds from middle weight lots were distributed in 15 pens with 10 of them in each pen as shown in Table 9. Three pens with 10 birds in each were selected randomly for each ration. The environmental conditions were kept identical. They were fed ad libitum and there was plenty of water to drink. The birds 
in each pen were weighed, the feed consumed in each pen was calculated, and the average weight gain per bird and the average feed consumption per bird per day were calculated. The F/G was calculated as before and the results are shown in Table 10-b.

C. The Development of a Method for Determining Thiol Amino Acids in the Fish Products Using Ag/S Specific-ion Electrode - "Ionalyzer Method"

The fish and fish products contain a limited amount of TAA ( $1 / 2$ cystine). The fish products, fish meal or fish protein concentrate, are not soluble in water or any other solvent to the extent that -SH can be determined with $\mathrm{AgNO}_{3}$ solution. To determine $-\mathrm{SH}$ in denatured protein, it must be in solution. The fish protein can be solubilized in three ways: by acid, by alkali or by enzymatic digestions. Of these three methods of solubilizing proteins, the enzymatic method of digestion of fish protein was selected. The reasons for selecting this method will be covered in the "Discussion" section.

It is, therefore, necessary to select a suitable proteolytic enzyme, to find a suitable $\mathrm{pH}$, temperature, and concentration for the particular enzyme selected for hydrolyzing the fish protain. A suitable buffer medium must be selected to maintain the level of the $\mathrm{pH}$ of the medium at a point at which the activity of enzyme on the substrate is not changed. Moreover, the buffer should not interfere in 
in any desired chemical reaction. One of the desired chemical reactions is:

$$
\mathrm{R}-\mathrm{SH}+\mathrm{AgNO}_{3} \longrightarrow \mathrm{R}-\mathrm{SAg}+\mathrm{HNO}_{3}
$$

so the buffer should not react with either -SH groups or the $\mathrm{AgNO}_{3}$.

In the AAA method, both cysteine and cystine are determined as $1 / 2$ cys (\%). In the Ionalyzer method, they, theoretically, may be determined either separately or combined. The $1 / 2$ cys value determined by the AAA method was small and it was not possible to separate cystine from cysteine. It may be suitable to report them as $1 / 2$ cys value to compare the results in both methods. The - SH groups are so unstable that they oxidize in atmospheric oxygen to -SS- groups, which can not be titrated with AgNO3. Therefore, it is necessary to find a suitable environment in which to conduct the experiment so that the -SH groups remain available to $\mathrm{AgNO}_{3}$ titration. $\mathrm{NaBH}_{4}$ was suggested as an appropriate reductant for -SS- groups in proteins by Harrap and Gruen [1971]. Considering the above mentioned facts, the experiments were conducted in the following manner.

(i) Study to find the suitability of titration using $\mathrm{AgNO}_{3}$ solution in the prospective buffer media for enzymatic hydrolysis of the protein of fish products

Two sets of experiments were conducted for this purpose. In one set, $10.0 \mathrm{ml}$ of $0.01 \mathrm{M}$ solution of each of L-cysteine, L-cysteine hydrochloride, L-cystine, glutathione and 2mercaptoethanol in distilled water was titrated with $0.1 \mathrm{M}$ 
$\mathrm{AgNO}_{3}$ solution previously standardized with $0.1 \mathrm{M} \mathrm{NaCl}$ solution using a $\mathrm{Ag} / \mathrm{S}$ specific-ion electrode along with a double junction reference electrode and an Ionalyzer as a potentiometer to detect the equivalence point. The experiments were conducted in triplicate. The L-cystine solution was titrated after reduction with $\mathrm{NaBH}_{4}(0.05 \mathrm{~g} / 5 \mu \mathrm{H}$ of -SS-). The results are tabulated in Table 13.

In the second set of experiments, $2.0 \mathrm{ml}$ of $0.1 \mathrm{M}$ L-cysteine hydrochloride solution in water was added to $18.0 \mathrm{ml}$ each of distilled water, $0.1 \mathrm{M}$ and $0.2 \mathrm{M}$ tris solutions ( $\mathrm{pH} \mathrm{7.0)} \mathrm{and} 0.1 \mathrm{M}$ and $0.01 \mathrm{M}$ imidazole solutions ( $\mathrm{pH} 7.0)$. The $\mathrm{pH}$ of both tris and imidazole solutions were adjusted to $\mathrm{pH} 7.0$ with $4.0 \mathrm{M} \mathrm{HNO}$. They were titrated with $0.1 \mathrm{M}$ $\mathrm{AgNO}_{3}$ solution. The percentage recovery is shown in Table 14. Imidazole solutions were found most suitable.

(ii) The selection of the enzyme for hydrolyzing FP The two proteolytic enzymes, subtilisin BPN' and collagenase (from Clostridium histolyticum) were selected for hydrolyzing the fish products because they are free from -SH and -SS- groups. Their respective proteolytic abilities were tested and the results are tabulated in Table 15. Subtilisin was found to be a more efficient protease than collagenase.

(iii) The study on the effect of enzymatic (subtilisin) hydrolysis of FP on $\mathrm{pH}$ value in imidazole buffer

Fifty $\mathrm{mg}$ of $\mathrm{FP}_{1}$ was added to $24.0 \mathrm{ml}$ of $0.1 \mathrm{M}$ imidazole buffer adjusted to the range of $\mathrm{pH} 4-10$, in a $50 \mathrm{ml}$ Erlenmyer flask. One $\mathrm{ml}$ of $10 \mathrm{mg} / \mathrm{ml}$ enzyme solution in $\mathrm{H}_{2} \mathrm{O}$ was added 
to each flask and was allowed to hydrolyze $\mathrm{FP}_{1}$ at $37 \mathrm{C}$ with constant stirring as suggested by the producer of the enzyme. The period of hydrolysis was 18 hours. The experiment was conducted in duplicate and the average $\mathrm{pH}$ values are tabulated in Table 16. In $0.1 \mathrm{M}$ imidazole buffer, the lowest change in $\mathrm{pH}$ was between $\mathrm{pH} 6.5$ and 7.5. Therefore, $\mathrm{pH} 7.0$ was selected for hydrolyzing FP with subtilisin BPN'.

(iv) Determination of $1 / 2$ cys content (\%) from hydrolyzates of fish products after 18 hours of digestion using $\mathrm{Ag} / \mathrm{S}$ specific-ion electrode

Fifty $\mathrm{mg}$ of a fish product ground in a "Hammer Mill" using a screen of 60 mesh was weighed in a $50 \mathrm{ml}$ Erlenmyer flask. Twenty-four $\mathrm{ml}$ of $0.1 \mathrm{M}$ imidazole buffer ( $\mathrm{pH} \mathrm{7.0)}$ and $1.0 \mathrm{ml}$ of $10 \mathrm{mg} / \mathrm{ml}$ freshly prepared substilisin BPN' solution in distilled water were added to flask and stoppered tightly. The FP was allowed to hydrolyze for 18 hours at $37 \mathrm{C}$ with continuous shaking in thermostatically controlled incubator. Each sample was hydrolyzed in triplicate. The hydrolyzates were transferred into $50 \mathrm{ml}$ centrifuge tubes and were centrifuged at $1600 \times \mathrm{k}$ for 15 minutes to remove the suspended particles. Twenty $\mathrm{ml}$ of clear hydrolyzate was transferred to a $100 \mathrm{ml}$ beaker. Two-tenths of one $\mathrm{ml}$ of 0.1 Na2 EDTA and a solution of 2 drops of octanol were added as chelating agent and anti-effervescent respectively. Fifty mg of $\mathrm{NaBH}_{4}$ was added as reducing agent. The whole mixture was allowed to react for 30 minutes at $40 \mathrm{C}$ in a water bath. Nitrogen gas was bubbled to keep atmospheric oxygen away, to remove any dissolved oxygen in the mixture, and to keep 
the mixture stirring.

At the end of reaction, all three samples were acidified with $4.0 \mathrm{M} \mathrm{HNO}_{3}$ to a $\mathrm{pH}$ between 3 and 4. One sample was titrated with $0.005 \mathrm{M} \mathrm{AgNO}_{3}$ solution using $\mathrm{Ag} / \mathrm{S}$ electrode in conjunction with a double junction $\mathrm{Ag} / \mathrm{AgCl}$ reference electrode and Ionalyzer as potentiometer. The equivalence point was noted from the sharp change in potential on Ionalyzer. Fifty to sixty per cent of $\mathrm{AgNO}_{3}$ solution required for titrating the first sample was added to the remaining two samples. They were allowed to react for 5 minutes under nitrogen atmosphere. Then the samples were neutralized to about $\mathrm{pH} 7.0$ with $1.0 \mathrm{M} \mathrm{NaOH}$ solution. Another portion of $50 \mathrm{mg}$ of $\mathrm{NaBH}_{4}$ was added and allowed to react for 15 minutes at room temperature under a nitrogen atmosphere. They were acidified to a $\mathrm{pH}$ between 3 and 4 with $1.0 \mathrm{M} \mathrm{HNO}_{3}$-Acetone $(I: I / v / v)$ solution. They were titrated with $\mathrm{AgNO}_{3}(0.005 \mathrm{M})$ solution.

The blanks were run with $24.0 \mathrm{ml}$ of $0.1 \mathrm{M}$ imidazole buffer, $1.0 \mathrm{ml}$ of enzyme solution, $0.2 \mathrm{ml}$ of $0.1 \mathrm{M} \mathrm{Na} 2 \mathrm{EDTA}$ solution, 2 drops of octanal and $100 \mathrm{mg}$ of $\mathrm{NaBH}_{4}$. They were mixed well and acidified with $1.0 \mathrm{M} \mathrm{HNO}_{3}$-Acetone mixture to a $\mathrm{pH}$ between 3 and 4 and were titrated with $\mathrm{AgNO}_{3}$ (0.005 M) solution to equivalence point which was indicated by the change of potential.

The $1 / 2$ cys value was calculated from the following formula as percentage ( $1 / 2$ cys $\%)$ : 
$1 / 2$ cys $\%=\frac{V X \text { X X MW X F X } 100}{S}$

$\begin{aligned} \mathrm{V}= & \text { Volume of Standardized } \mathrm{AgNO}_{3} \text { solution } \\ \mathrm{M} & =\text { Molarity of } \mathrm{AgNO}_{3} \text { solution } \\ \mathrm{MW} & =1 / 2 \times \text { Molecular weight of L-cystine (free base) } \\ \mathrm{S} & =\text { Weight of the fish product used in the } \\ & \quad \text { experiment } \mathrm{x} \frac{\% \text { protein in the fish product }}{100} \\ = & \text { for calculating percentage } \\ \mathrm{F} & =\frac{\text { Total vol. of hydrolyzate }}{\text { Titrated vol. of hydrolyzate }}\end{aligned}$

The fish products $\mathrm{FP}_{1}, \mathrm{FP}_{3}-\mathrm{FP}_{6}$ were analyzed by this method and the results are tabulated in Table 17.

The $1 / 2$ cys (\%) values were much lower in this method than the AAA method. But the figures still indicated the method of processing which retained more TAA than the other. Considering the results of the above mentioned preliminary experiments, it was favored to improve the experimental condition of determining $1 / 2$ cys, reduce the period of hydrolysis and to find optimum $\mathrm{pH}$, temperature and enzyme concentration on FP as its substrate. In addition, the effect of suspensoid, concentration of urea and enzyme concentration on 18 hour hydrolysis were studied.

(i) Study on the effect of the concentration of enzyme on fish product in 18 hour hydrolysis

Fifty $\mathrm{mg}$ of $\mathrm{FP}_{1}$ in $24.0 \mathrm{ml}$ of $0.1 \mathrm{M}$ imidazole buffer (pH 7.0) was hydrolyzed with $1.0 \mathrm{ml}$ of each of $0.5 \mathrm{mg}, 1.0$ $\mathrm{mg}, 2.0 \mathrm{mg}, 5.0 \mathrm{mg}, 10 \mathrm{mg}$ and $20.0 \mathrm{mg}$ of enzyme per $\mathrm{ml}$ respectively for 18 hours at $37 \mathrm{C}$ in shaker-incubator with 
with constant shaking. The amount of $1 / 2$ cys (\%) was determined from the amount of $0.005 \mathrm{M} \mathrm{AgNO}_{3}$ required to titrate the -SH groups liberated following the procedure stated earlier. The results are tabulated in Table 18.

(vi) Study on the effect of suspended particles in the hydrolyzate on - SH in titration

Fifty $\mathrm{mg}$ of $\mathrm{FP}_{1}$ in $24.0 \mathrm{ml}$ of $0.1 \mathrm{M}$ imidazole buffer ( $\mathrm{pH} 7.0$ ) was hydrolyzed with $1.0 \mathrm{ml}$,of $10 \mathrm{mg} / \mathrm{ml}$ of enzyme solution at $37 \mathrm{C}$ for 18 hours. Six samples were hydrolyzed. Three of them were centrifuged at $1600 \times$ G for 15 minutes to remove suspended particles. One sample from each of clear and unclear hydrolyzates were used to determine the amount of $\mathrm{AgNO}_{3}$ solution required to add after first reduction. The $1 / 2$ cys (\%) was determined in duplicate with the remaining two samples from both types of hydrolyzate. No significant differences in the levels of $1 / 2$ cys were observed between the two methods of treatment made to the protein hydrolyzates of $\mathrm{FP}_{1}$. The results are tabulated in Table 19.

(vii) Study on the effect of urea on $1 / 2$ cys value in FP hydrolyzates

Nine samples of $\mathrm{FP}_{1}$ (50 mg) were hydrolyzed with $1 \mathrm{ml}$ of subtilisin (10 mg/ml) for 18 hours at $37 \mathrm{C}$ as before. In the first three samples $1.2 \mathrm{~g}$, in the second three samples $2.4 \mathrm{~g}$ and in the last three samples $4.8 \mathrm{~g}$ of urea were added to each of those samples to raise the concentration of urea to $4.0,8.0$ and $16.0 \mathrm{M}$ respectively. The $1 / 2$ cys content was determined in those samples by the procedure already 
described and the results are tabulated in Table 20. No significant differences between treatments were observed.

(viii) Digestibility of fish protein at different temperatures

The protein of fish products prepared from herring and menhaden were hydrolyzed at $\mathrm{pH} 7.0$ using $0.1 \mathrm{M}$ imidazole buffer at $37,43,50$ and $56 \mathrm{C}$ for 3 hours with continuous stirring in a thermostatically controlled magnetic stirrer incubator. One-half $\mathrm{g}$ of $\mathrm{FP}_{7}$ and FP8 from herring and FP9 and $\mathrm{FP}_{11}$ from menhaden were hydrolyzed using $1 \mathrm{ml}$ of 10 $\mathrm{mg} / \mathrm{ml}$ of subtilisin BPN' and $49 \mathrm{ml}$ of buffer. After digestion, the hydrolyzates were treated with $1.0 \mathrm{ml}$ of $4 \mathrm{~N}$ $\mathrm{HCl}$ to inactivate the enzyme by lowering the $\mathrm{pH}$ below 3 . The hydrolyzates were mixed with $1 \mathrm{~g}$ of filter aid (HyfloSuper cell). The mixture was filtered using No. I filter paper and an aspirator. The residue was washed with water and rewashed with $50 \mathrm{ml}$ warm water $(70-80 \mathrm{C}$ ) by adding about $16 \mathrm{ml}$ at a time. The nitrogen in the residue was determined by the macro-Kjeldahl method. The undigested crude protein was calculated and the percentage of protein digested was calculated and reported in Table 21.

The optimum temperature for hydrolyzing fish protein with subtilisin BPN' was between 50 and $56 \mathrm{C}$.

(ix) Digestibility of fish protein in fish products at different $\mathrm{pH}$ with subtilisin $\mathrm{BPN}$ :

One-half $\mathrm{g}$ of $\mathrm{FP}_{7}, \mathrm{FP}_{8}, \mathrm{FP}_{9}$, and $\mathrm{FP}_{11}$ were digested with $1 \mathrm{ml}$ of $10 \mathrm{mg} / \mathrm{ml}$ of enzyme and $49 \mathrm{ml}$ of $0.1 \mathrm{M}$ imidazole buffer at $\mathrm{pH} 4.0,5.5,7.0$ and 8.5 respectively at $50 \mathrm{C}$ for 
a period of 3 hours. The digestibility was calculated and reported in Table 22 following the procedure mentioned above. It was observed that the optimum $\mathrm{pH}$ was around $\mathrm{pH} 5.5$. But considering the results at $\mathrm{pH} 4.0$ and 7.0 , it seemed that the optimum $\mathrm{pH}$ for hydrolysis of fish protein with subtilisin would be between $\mathrm{pH} 5.5$ and 7.0 and not between $\mathrm{pH} 5.5$ and 4.0.

(x) Digestibility of fish protein in fish products at different length of periods of digestion using subtilisin BPN'

One $g$ of each of $\mathrm{FP}_{7}, \mathrm{FP} 8, \mathrm{FP}$, and $\mathrm{FP}_{11}$ was digested with $1.0 \mathrm{ml}$ of $10 \mathrm{mg} / \mathrm{ml}$ of enzyme solution and in $99 \mathrm{ml}$ of $0.1 \mathrm{M}$ imidazole buffer $\mathrm{pH} 7.0$ at $50 \mathrm{C}$ in duplicate. They were digested for 1 hour, 3 hours, and 6 hours. The digestibility of FP was calculated and reported in Table 23, following the method described in (viii) above.

There was considerable difference between $I$ hour and 3 hour digestion, but the difference was not significant between 3 hour and 6 hour digestion times.

(xi) The effect of enzyme concentration on fish protein hydrolysis in a period of 3 hours

One $g$ of each $\mathrm{FP}_{7}, \mathrm{FP}_{8}, \mathrm{FP}_{9}$, and $\mathrm{FP}_{11}$ was digested in $99 \mathrm{ml}$ of $0.1 \mathrm{M}$ imidazole buffer ( $\mathrm{pH} \mathrm{7.0)}$ with $1 \mathrm{ml}$ of $1.0,2.0,5.0$ and $10.0 \mathrm{mg} / \mathrm{ml}$ of enzyme solution at $50 \mathrm{C}$ for a period of 3 hours. The digestibility was calculated as mentioned in (viii) above and reported in Table 24. There was little difference in digestibility at the enzyme concentrations at the 5.0 and $10.0 \mathrm{mg}$ levels. 
(xii) Determination of $1 / 2$ cys (\% in fish products Fifty $\mathrm{mg}$ of each of $\mathrm{FP}_{7}-\mathrm{FP}_{11}$ in $49 \mathrm{ml}$ of $0.1 \mathrm{M}$ imidazole buffer ( $\mathrm{pH}$ 7.0) were hydrolyzed with $1 \mathrm{ml}$ of 10 $\mathrm{mg} / \mathrm{ml}$ of the enzyme (subtilisin BPN') solution at $50 \mathrm{C}$ for a period of 3 hours in triplicate under nitrogen atmosphere. The $1 / 2$ cys was determined following the procedure described in (iv) above omitting the centrifugation of the hydrolyzates. The results are tabulated in Table 25. The experiment was repeated with $100 \mathrm{mg}$ and $\mathrm{FP}_{7}-\mathrm{FP}_{11}$ in $99 \mathrm{ml}$ of the same buffer and 1.0 of enzyme $(10 \mathrm{mg} / \mathrm{ml})$. There were no differences in results. 
Table 1 - Chemical composition of ground whole fish***

\begin{tabular}{lcccc}
\hline Name of Fish & Protein $^{*}$ & T $_{\%} V^{* *}$ & Fat $_{\%}$ & Ash $_{\%}$ \\
\hline Herring & 17.4 & 71.7 & 6.9 & 2.6 \\
Menhaden & 15.2 & 72.5 & 5.4 & 6.2 \\
\hline
\end{tabular}

${ }^{*}$ Crude protein ( $\left.\mathrm{N} \times 6.25\right)$

${ }^{* *}$ T.V. = total volatiles

***Average of duplicate determinations 
Table 2 - Chemical composition and pepsin digestibility of fish products*

\begin{tabular}{|c|c|c|c|c|c|}
\hline $\begin{array}{l}\text { Fish } \\
\text { Products } \\
\end{array}$ & $\begin{array}{c}\text { Protein } \\
\%\end{array}$ & $\begin{array}{c}\text { T.V. } \\
\%\end{array}$ & $\begin{array}{c}\text { Fat } \\
\%\end{array}$ & $\begin{array}{c}\text { Ash } \\
\%\end{array}$ & $\begin{array}{l}\text { Pepsin } \\
\text { Digestibility }\end{array}$ \\
\hline \multicolumn{6}{|l|}{ Herring } \\
\hline $\mathrm{FP}_{1}$ & 80.7 & 5.0 & 4.1 & 10.3 & 93.0 \\
\hline $\mathrm{FP}_{2}$ & 79.5 & 5.4 & 4.8 & 10.3 & 97.2 \\
\hline $\mathrm{FP}_{3}$ & $77 \cdot 3$ & 4.4 & 12.3 & 9.5 & 96.9 \\
\hline $\mathrm{FP}_{4}$ & 82.5 & 3.4 & 0.6 & 8.8 & 96.7 \\
\hline $\mathrm{FP}_{5}$ & 68.2 & 4.0 & 20.8 & 9.9 & --- \\
\hline $\mathrm{FP}_{6}$ & 80.0 & 7.6 & 0.5 & 11.3 & 89.4 \\
\hline $\mathrm{FP}_{7}$ & 76.5 & 11.2 & 2.6 & 8.7 & 95.1 \\
\hline $\mathrm{FP}_{8}$ & 76.2 & 10.8 & 3.5 & 9.1 & 91.1 \\
\hline \multicolumn{6}{|l|}{ Menhaden } \\
\hline $\mathrm{FP}_{9}$ & 66.2 & 8.3 & 1.9 & 23.6 & 90.5 \\
\hline $\mathrm{FP}_{10}$ & 64.3 & 7.7 & 2.5 & 20.6 & 88.5 \\
\hline $\mathrm{FP}_{11}$ & 66.3 & 1.1 & 12.5 & 23.6 & 87.0 \\
\hline
\end{tabular}

*Average of duplicate determinations 
Table 3 - Amino acid composition of fish products

\begin{tabular}{|c|c|c|c|c|c|c|c|c|c|c|}
\hline \multirow[t]{2}{*}{$\begin{array}{l}\text { Amino } \\
\text { Acid }\end{array}$} & \multicolumn{10}{|c|}{ Fish proteins - \% Amino Acid (N X 6.25) } \\
\hline & $\mathrm{FP}_{1}$ & $\mathrm{FP}_{3}$ & $\mathrm{FP}_{4}$ & $\mathrm{FP}_{5}$ & $\mathrm{FP}_{6}$ & $\mathrm{FP}_{7}$ & $\mathrm{FP}_{8}$ & $\mathrm{FP}_{9}$ & $\mathrm{FP}_{10}$ & $\mathrm{FP}_{11}$ \\
\hline $\mathrm{Ala}$ & 7.1 & 7.1 & 8.1 & 8.0 & 6.9 & 8.8 & 8.5 & 9.4 & 7.4 & 9.0 \\
\hline Arg & 6.1 & 7.0 & 6.8 & 7.6 & 7.1 & 7.6 & 6.8 & 7.6 & 8.9 & 8.8 \\
\hline Asp & 10.8 & 10.9 & 12.3 & 12.4 & 12.7 & 12.5 & 12.1 & 13.0 & 12.4 & 12.1 \\
\hline 1/2 Cys & 1.20 & 0.55 & 1.10 & 0.60 & 0.70 & 1.00 & 0.60 & 1.10 & 0.85 & 0.60 \\
\hline Glu & 12.4 & 8.3 & 9.2 & 10.6 & 7.8 & 12.9 & 12.8 . & 14.0 & 12.8 & 14.9 \\
\hline Gly & 4.9 & 5.1 & 4.0 & 6.8 & 4.9 & 6.6 & 7.1 & 7.1 & 8.5 & 6.7 \\
\hline His & 2.2 & 2.6 & 2.5 & 2.4 & 2.6 & 2.3 & 2.2 & 3.2 & 3.2 & 2.4 \\
\hline Ilu & 5.0 & 6.8 & 5.1 & 5.8 & 7.2 & 6.4 & 6.2 & 4.6 & 5.0 & 5.5 \\
\hline Leu & 8.1 & 8.4 & 8.3 & 8.4 & 8.8 & 8.2 & 8.7 & 7.3 & 8.2 & 8.8 \\
\hline Lys & 10.8 & 10.5 & 12.5 & 11.2 & 9.2 & 14.6 & 13.8 & 16.5 & 11.7 & 12.2 \\
\hline Met & 2.6 & 3.2 & 2.7 & 3.8 & 3.5 & 3.5 & 2.9 & 2.7 & 2.4 & 2.4 \\
\hline
\end{tabular}


Table 3 - Amino acid composition of fish products (Continued)

\begin{tabular}{|c|c|c|c|c|c|c|c|c|c|c|}
\hline \multirow{3}{*}{$\begin{array}{l}\text { Amino } \\
\text { Acid }\end{array}$} & \multicolumn{10}{|c|}{ Fish proteins - \% Amino Acid ( $\mathrm{N} \times 6.25$ ) } \\
\hline & \multicolumn{7}{|c|}{ Herring } & \multicolumn{3}{|c|}{ Menhaden } \\
\hline & $\mathrm{FP}_{1}$ & $\mathrm{FP}_{3}$ & $\mathrm{FP}_{4}$ & $\mathrm{FP}_{5}$ & $\mathrm{FP}_{6}$ & $\mathrm{FP}_{7}$ & $\mathrm{FP}_{8}$ & $\mathrm{FP}_{9}$ & $\mathrm{FP}_{10}$ & $\mathrm{FP}_{11}$ \\
\hline Phe & 7.4 & 5.7 & 3.6 & 4.2 & 6.9 & 4.0 & 3.8 & 4.1 & 4.6 & 3.6 \\
\hline Pro & 3.5 & 5.5 & 4.0 & 4.0 & 6.6 & --- & -- & -- & -- & -- \\
\hline Ser & 4.6 & 4.3 & 4.9 & 5.4 & 5.0 & 4.8 & 3.3 & 5.5 & 5.9 & 5.7 \\
\hline Thr & 4.5 & 4.3 & 5.3 & 5.6 & 4.4 & 4.8 & 4.7 & 5.1 & 5.5 & 5.6 \\
\hline Tyr & 2.9 & 4.6 & 3.4 & 2.9 & 4.7 & 3.1 & 2.2 & 2.9 & 3.5 & 3.2 \\
\hline Val & 4.5 & 7.0 & 6.8 & 7.1 & 6.4 & 6.5 & 7.1 & 4.9 & 4.7 & 6.2 \\
\hline
\end{tabular}


Table 4 - Relationship between lipid oxidation and TAA disappearance ${ }^{*}$

\begin{tabular}{ccc}
\hline $\begin{array}{l}\text { Period of } \\
\text { Oxidation } \\
(\text { week) }\end{array}$ & $\begin{array}{c}\text { Peroxide } \\
\text { Value }\end{array}$ & $\begin{array}{c}1 / 2 \text { Cys* } \\
\text { Determined } \\
\%\end{array}$ \\
\hline 0 & 10.0, & 0.093 \\
1 & 21.7 & 0.068 \\
3 & 31.9 & 0.048 \\
4 & 61.6 & 0.046 \\
5 & 75.6 & 0.045 \\
\hline
\end{tabular}

* Oxidation of dehydrated cake at ambient temperature from which $\mathrm{FP}_{8}$ was prepared.

**Determined by Ionalyzer method. 
Table 5 - Experimental diets (21\% Protein)

\begin{tabular}{|c|c|c|c|c|c|c|}
\hline Ingredient & $\begin{array}{l}\text { Protein } \\
\%\end{array}$ & $\begin{array}{c}\text { Ingred } \\
\mathrm{DI}\end{array}$ & $\begin{array}{l}\text { ient - } \\
\text { D2 }\end{array}$ & $\begin{array}{r}\mathrm{g} / \mathrm{Kg} \\
\mathrm{D} 3\end{array}$ & of $\frac{\text { aiet }}{\mathrm{D} 4}$ & t \\
\hline $\mathrm{FP}_{7}$ & 76.5 & 52.3 & --- & -- & -- & -- \\
\hline $\mathrm{FP}_{8}$ & 76.2 & --- & 52.5 & -- & -- & $\cdots$ \\
\hline $\mathrm{FP}_{9}$ & 66.2 & --- & -- & 60.4 & -- & -- \\
\hline $\mathrm{FP}_{10}$ & 64.3 & -- & -- & -- & 62.2 & -- \\
\hline $\mathrm{FP}_{11}$ & 66.3 & --- & -- & -- & -- & 60. \\
\hline SBOM & 51.0 & 230 & 230 & 230 & 230 & 230 \\
\hline GYCM & 9.0 & 566 & 566 & 552 & 550 & 561 \\
\hline Alfalfa Meal & 17.0 & 20 & 20 & 20 & 20 & 20 \\
\hline Fat & & 93 & 93 & 99 & 99 & 90 \\
\hline Dical & & 25 & 25 & 25 & 25 & 25 \\
\hline Salt & & 4 & 4 & 4 & 4 & 4 \\
\hline Trace Element Mixture & & 5 & 5 & 5 & 5 & 5 \\
\hline Vitamin Mixture & & 5 & 5 & 5 & 5 & 5 \\
\hline Protein in Diets (\%) & & 21 & 21 & 21 & 21 & 21 \\
\hline $\begin{array}{l}\text { Metabolizable energy } \\
\text { cal/Kg }\end{array}$ & & 3485 & 3489 & 3489 & 3486 & 3488 \\
\hline
\end{tabular}


Table 6 - Experimental diets (18\% protein)

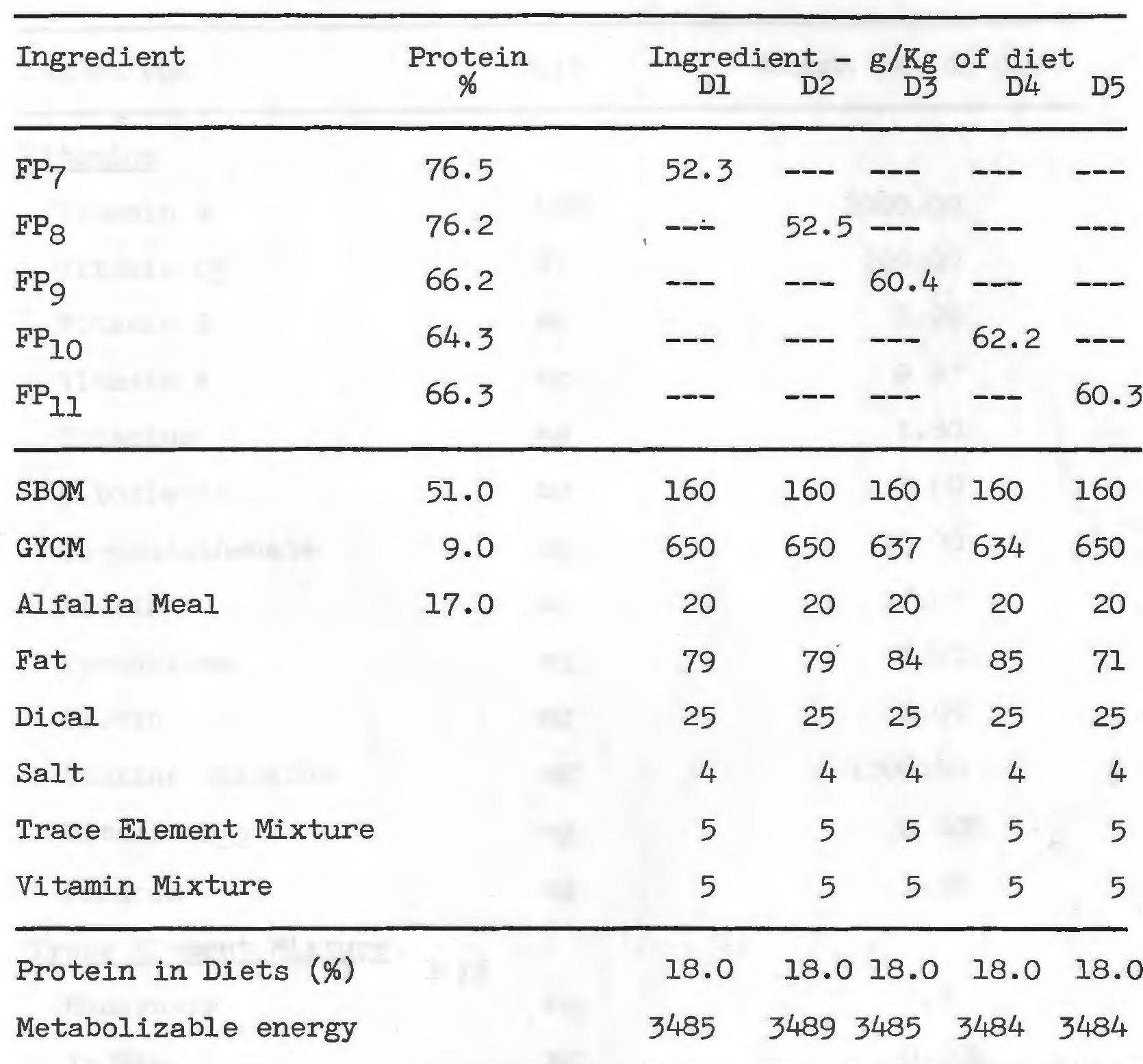


Table 7 - Composition of vitamins and trace element mixtures for experimental diets

Vitamins

Vitamin A

USP

Vitamin $\mathrm{D}_{3}$

Vitamin $\mathrm{E}$

Vitamin $\mathrm{K}$

Thiamine

Riboflavin

Ca-pantothenate

Niacin

Pyridozine

Biotin

Choline chloride

Vitamin $\mathrm{B}_{12}$

Folacin

Trace Element Mixture

Manganese

Iodine

Iron

Zinc

Copper

Cobalt

\section{IU}

mg

mg

$\mathrm{mg}$

mg

mg

mg

mg

mg

mg

mg

$\mathrm{mg}$

mg

$\mathrm{mg}$

$\mathrm{mg}$

$\mathrm{mg}$

$\mathrm{mg}$

mg

$$
\begin{array}{r}
2000.00 \\
200.00 \\
2.20 \\
0.53 \\
1.80 \\
3.60 \\
10.00 \\
27.00 \\
3.00 \\
0.09
\end{array}
$$

1300.00

0.009

1.20

0.3

0.006

0.1

0.1

0.01

0.001 
Table 8 - Distribution of birds in pens for testing experimental diet (2l\% protein)

\begin{tabular}{|c|c|c|c|c|c|c|c|c|c|c|c|c|c|c|c|c|}
\hline \multicolumn{4}{|c|}{ Weight of Brids ( $\mathrm{g}$ ) } & Pen & \multicolumn{3}{|c|}{ Number with } & \multicolumn{8}{|c|}{ Number of Birds of Different Weight } & \multirow{2}{*}{$\begin{array}{c}\text { Range } \\
15\end{array}$} \\
\hline Range & Average & 1 & 2 & 3 & 4 & 5 & 6 & 7 & 8 & 9 & 10 & 11 & 12 & 13 & 14 & \\
\hline $45-49$ & 47.0 & 4 & 4 & 4 & 4 & 4 & 4 & 4 & 4 & 4 & 4 & 4 & 4 & 3 & 3 & 3 \\
\hline $50-54$ & 52.0 & 4 & 4 & 4 & 4 & 4 & 4 & 4 & 4 & 4 & 4 & 3 & 3 & 4 & 4 & 4 \\
\hline $55-59$ & 57.0 & 2 & 2 & 2 & 2 & 2 & 2 & 2 & 2 & 1 & 1 & 2 & 2 & 2 & 2 & 2 \\
\hline $60-64$ & 62.0 & 0 & 0 & 0 & 0 & 0 & 0 & 0 & 0 & 1 & $I$ & 1 & 1 & 1 & 1 & 1 \\
\hline \multicolumn{2}{|c|}{$\begin{array}{l}\text { Average Weight } \\
\text { per Bird }(g)\end{array}$} & 51 & 51 & 51 & 51 & 51 & 51 & 51 & 51 & 51.5 & 51.5 & 552 & 52 & 52.5 & 52.5 & 52.5 \\
\hline
\end{tabular}


Table 9 - Distribution of birds in pens for testing experimental diet (18\% protein)

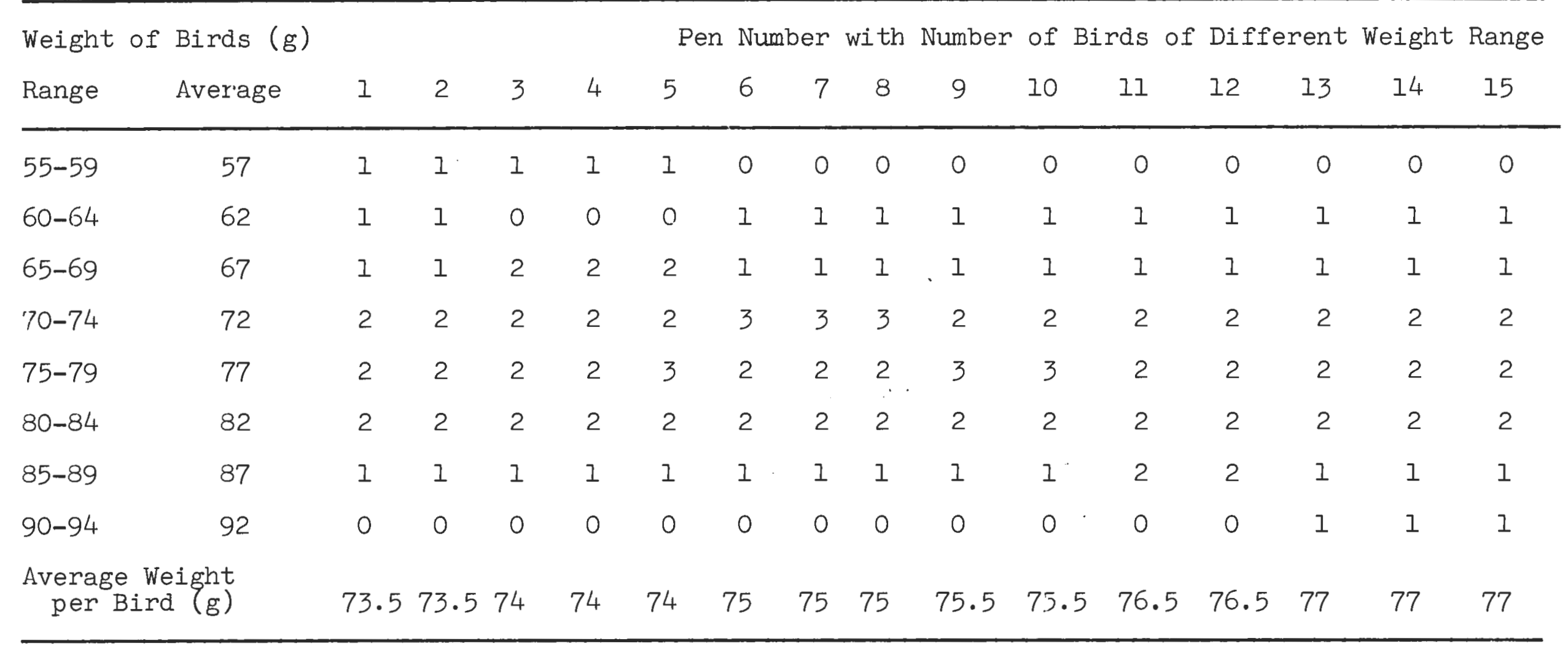


Table 10 (a) - Results of a ten-day bio-assay of fish products using experimental diets (2l\% protein)

\begin{tabular}{|c|c|c|c|c|}
\hline Rations & $\begin{array}{l}\text { Average Feed } \\
\text { Consumption } \\
\text { per Chick } \\
\text { per Day } \\
\quad(\mathrm{g})\end{array}$ & $\begin{array}{l}\text { Weight Gained } \\
\text { per Chick } \\
\text { per Day } \\
\qquad(\mathrm{g})\end{array}$ & $\begin{array}{l}\text { Feed Consumed } \\
\text { per Chick per } \\
\text { Day: Wt. } \\
\text { Gained per } \\
\text { Chick per day }\end{array}$ & Remarks \\
\hline DI & $20.40 \pm .27$ & $14.50 \pm 0.58$ & $1.40 \pm 0.02$ & $\begin{array}{l}\text { Ration } \mathrm{Dl} \text { was formu- } \\
\text { lated using } \mathrm{FP}_{7}\end{array}$ \\
\hline $\mathrm{D} 2$ & $20.60 \pm .41$ & $13.80 \pm 0.68$ & $1.49 \pm 0.01$ & $\begin{array}{l}\text { Ration } \mathrm{D} 2 \text { was formu- } \\
\text { lated using } \mathrm{FP}_{8}\end{array}$ \\
\hline D3 & $20.10 \pm .38$ & $13.80 \pm 0.63$ & $1.45 \pm 0.007$ & $\begin{array}{l}\text { Ration } D 3 \text { was formu- } \\
\text { lated using } \mathrm{FP}_{9}\end{array}$ \\
\hline $\mathrm{D} 4$ & $20.10 \pm .16$ & $13.70 \pm 0.67$ & $1.46 \pm 0.05$ & $\begin{array}{l}\text { Ration } \mathrm{D} 4 \text { was formu- } \\
\text { lated using } \mathrm{FP}_{10}\end{array}$ \\
\hline D5 & $22.30 \pm .58$ & $14.40 \pm 0.87$ & $1.54 \pm 0.03$ & $\begin{array}{l}\text { Ration } \mathrm{D} 5 \text { was formu- } \\
\text { lated using } \mathrm{FP}_{11} \\
\text { (control) }\end{array}$ \\
\hline
\end{tabular}


Table 10 (b) - Results of a ten-day bio-assay of fish products using experimental diets ( $18 \%$ protein)

\begin{tabular}{|c|c|c|c|c|}
\hline Rations & $\begin{array}{l}\text { Average Feed } \\
\text { Consumption } \\
\text { per Chick } \\
\text { per Day } \\
\quad(g)\end{array}$ & $\begin{array}{l}\text { Weight Gained } \\
\text { per Chick } \\
\text { per Day } \\
\quad(g)\end{array}$ & $\begin{array}{l}\text { Feed Consumed } \\
\text { per Chick per } \\
\text { Day: Wt. } \\
\text { Gained per } \\
\text { Chick per day }\end{array}$ & Remarks \\
\hline $\mathrm{D} 1$ & $26.85 \pm 1.3$ & $12.02 \pm 0.97$ & $2.23 \pm 0.18$ & $\begin{array}{l}\text { Ration } \mathrm{Dl} \text { was formu- } \\
\text { lated using } \mathrm{FP}_{7}\end{array}$ \\
\hline $\mathrm{D} 2$ & $27.73 \pm 1.9$ & $12.36 \pm 0.27$ & $2.24 \pm 0.18$ & $\begin{array}{l}\text { Ration } \mathrm{D} 2 \text { was formu- } \\
\text { lated using } \mathrm{FP}_{8}\end{array}$ \\
\hline D3 & $28.82 \pm 0.4$ & $13.36 \pm 0.58$ & $2.15 \pm 0.074$ & $\begin{array}{l}\text { Ration } \mathrm{D} 3 \text { was formu- } \\
\text { lated using } \mathrm{FP}_{9}\end{array}$ \\
\hline D4 & $29.29 \pm 1.5$ & $13.35 \pm 0.69$ & $2.19 \pm 0.105$ & $\begin{array}{l}\text { Ration } \mathrm{D} 4 \text { was formu- } \\
\text { lated using } F P_{10}\end{array}$ \\
\hline D5 & $26.32 \pm 1.7$ & $11.54 \pm 0.42$ & $2.28 \pm .002$ & $\begin{array}{l}\text { Ration D5 was formu- } \\
\text { lated using } \mathrm{FP}_{11} \\
\text { (control) }\end{array}$ \\
\hline
\end{tabular}


Table 11 - Amino acid requirement ${ }^{*}$, amino acid comparison of experimental diets (2l\% protein) and $F: G^{* *}$ by a chick in a loday feeding test

\begin{tabular}{|c|c|c|c|c|c|c|}
\hline \multirow{2}{*}{ Amino Acid } & \multirow{2}{*}{$\begin{array}{c}\text { Amino Acid } \\
\text { Requirement } \\
\%\end{array}$} & \multicolumn{4}{|c|}{ Amino Acid Composition-\% } & \multirow[b]{2}{*}{ D5 } \\
\hline & & $\mathrm{Dl}$ & D2 & D3 & D4 & \\
\hline Arg & 1.40 & 1.36 & 1.27 & 1.29 & 1.35 & 1.34 \\
\hline Gly \& Ser & 1.15 & 2.09 & 2.09 & 2.04 & 2.10 & 2.02 \\
\hline His & 0.46 & 0.45 & 0.45 & 0.45 & 0.45 & 0.45 \\
\hline Ile & 0.86 & 1.09 & 1.09 & 1.01 & 1.03 & 1.05 \\
\hline Leu & 1.60 & 1.68 & 1.71 & 1.64 & 1.68 & 1.70 \\
\hline Lys & 1.25 & 1.41 & 1.38 & 1.49 & 1.29 & 1.31 \\
\hline Phe \& Tyr & $1.5(.8+.7)$ & 1.37 & 1.32 & 1.35 & 1.40 & 1.35 \\
\hline Thr & 0.8 & 0.78 & 0.78 & 0.79 & 0.81 & 0.82 \\
\hline Val & 1.0 & 1.02 & 1.04 & 0.94 & 0.93 & 1.0 \\
\hline SAA & 0.86 & 0.51 & 0.46 & 0.44 & 0.44 & 0.45 \\
\hline (Met \& Cys) & $(0.46+0.4)$ & $(.32+.19)$ & $(.29+.17)$ & $(.28+.16)$ & $(.27+.17)$ & $(.28+.17)$ \\
\hline F:G (Feed:Gain) & & 1.40 & 1.49 & 1.45 & 1.46 & 1.54 \\
\hline
\end{tabular}

*Amino acid requirement by chicks (0-6 weeks) as recommended by NAS [1971].

**Feed conversion expressed as a ratio of feed consumed to weight gained. 
Table 12 - Amino acid requirement, amino acid composition of experimental diets (18\% protein) and $F: G^{* *}$ by a chick in a 10-day feeding test

\begin{tabular}{lcccccc}
\hline & $\begin{array}{c}\text { Amino Acid } \\
\text { Amino Acid }\end{array}$ & \multicolumn{5}{c}{ Amino Acid Composition $-\%$} \\
& \% & D1 & D2 & D3 & D4 & D5 \\
\hline Arg & 1.4 & 1.11 & 1.08 & 1.11 & 1.16 & 1.17 \\
Gly \& Ser & 1.15 & 1.47 & 1.53 & 1.50 & 1.56 & 1.48 \\
His & 0.46 & 0.38 & 0.38 & 0.38 & 0.38 & 0.38 \\
Ilu & 0.86 & 0.95 & 0.95 & 0.88 & 0.89 & 0.92 \\
Leu & 1.60 & 1.53 & 1.56 & 1.46 & 1.52 & 1.55 \\
Lys & 1.25 & 1.19 & 1.18 & 1.29 & 1.09 & 1.11 \\
Phe \& Tyr & $1.5(.8+7)$ & 1.16 & 1.11 & 1.15 & 1.19 & 1.14 \\
Thr & 0.8 & 0.69 & 0.69 & 0.71 & 0.73 & 0.73 \\
Val & 1.0 & 0.88 & 0.90 & 0.81 & 0.81 & 0.82 \\
SAA & 0.86 & 0.50 & 0.45 & 0.45 & 0.43 & 0.43 \\
(Met \& Cys) & $(0.46+0.4)$ & $(0.29+0.21)(0.26+0.19)(0.26+0.19)(0.24+0.19)(0.24+0.19)$ \\
F:G (Feed:Gain) & & 2.23 & 2.24 & 2.15 & 2.19 & 2.28 \\
\hline
\end{tabular}

*Amino acid requirement by chicks (0-6 weeks) as recommended by NAS [1971].

**Feed conversion expressed as a ratio of feed consumed to weight gained. 
Table 13 - Recovery of -SH compounds dissolved in distilled water by Ionalyzer method

Compound

Recovery - \%

Cysteine (free base)

$100 \pm 6$

2-Mercaptoethanol

$100 \pm 6$

Glutathione

$100 \pm 6$

Cystine (free base)

$100 \pm 6$

Cysteine hydrochloride

$233 \pm 5$ 
Table 14 - Study to find out a suitable media for titrating $-\mathrm{SH}^{*}$ compound using AgNO3 solution by Ionalyzer method

\begin{tabular}{ll}
\hline Medium & Recovery $-\%$ \\
\hline Distilled Water & 233 \\
Tris $(0.1 \mathrm{M})$ & 227 \\
Tris $(0.2 \mathrm{M})$ & 133 \\
Imidazole $(0.1 \mathrm{M})$ & 101 \\
Imidazole $(0.01 \mathrm{M})$ & 101 \\
\hline
\end{tabular}

*The thiol compound was cysteine hydrocholoride 

Table 15 - Selection of enzyme for hydrolyzing protein
of fish products*

\begin{tabular}{lccl} 
Enzyme & $\begin{array}{c}\text { Amount of } \\
\text { Enzyme }(\mathrm{mg})\end{array}$ & $\begin{array}{c}\text { Substrate-FPI } \\
(\mathrm{mg})\end{array}$ & $\begin{array}{c}\mathrm{AgNO}_{3} \\
(\mathrm{O} . \mathrm{IM}) \\
\mathrm{ml}\end{array}$ \\
\hline Subtilisin BPN' & 2.0 & 0 & 0.00 \\
1.0 & 50 & 0.062 \\
& 2.0 & 50 & 0.125 \\
\hline Collagenase & 2.0 & 0 & 0.00 \\
& 1.0 & 50 & 0.008 \\
& 2.0 & 50 & 0.016 \\
\hline
\end{tabular}

${ }^{*}$ Protein was hydrolyzed at $37 \mathrm{C}$ in $0.1 \mathrm{M}$ imidazole $(\mathrm{pH} 7.0)$ for 18 hours. 
Table 16 - Change in pH of 0.1M imidazole buffer during enzymatif hydrolysis of protein of fish products

\begin{tabular}{rcc} 
Initial pH & Final pH & Change of $\mathrm{pH}$ \\
\hline 4.00 & 5.70 & +1.70 \\
5.50 & 5.80 & +0.30 \\
6.50 & 6.35 & +0.15 \\
7.50 & 7.40 & -0.10 \\
8.50 & 8.25 & -0.25 \\
10.00 & 8.50 & -1.50
\end{tabular}

* $50 \mathrm{mg} \mathrm{FP}$ was hydrolyzed with $10 \mathrm{mg}$ subtilisin BPN' at $37 \mathrm{C}$ for 18 hours. 
Table 17 - Comparison of $1 / 2$ cystine values determined by Ionalyzer method and amino acid Autoanalyzer method

\begin{tabular}{|c|c|c|c|}
\hline \multirow[b]{2}{*}{$\begin{array}{l}\text { Fish } \\
\text { Products }\end{array}$} & \multirow[b]{2}{*}{$\begin{array}{l}\text { Ionalyzer } \\
\text { Method }\end{array}$} & \multicolumn{2}{|c|}{ Cystine Values - $1 / 2$ Cys (\%) } \\
\hline & & $\begin{array}{l}\text { AAA }^{* *} \\
\text { Method }\end{array}$ & $\frac{\text { Ionalyzer Method X } 100}{\text { AAA Method }}$ \\
\hline $\mathrm{FP}_{1}$ & 0.30 & 1.20 & 25.0 \\
\hline $\mathrm{FP}_{3}$ & 0.18 & 0.55 & 32.7 \\
\hline $\mathrm{FP}_{4}$ & 0.22 & 1.10 & 20.0 \\
\hline $\mathrm{FP}_{5}$ & 0.07 & 0.60 & 12.0 \\
\hline $\mathrm{FP}_{6}$ & 0.10 & 0.70 & 14.3 \\
\hline
\end{tabular}

*Enzymatic hydrolysis was conducted at $\mathrm{pH} 7.0$ and $37 \mathrm{C}$ for 18 hours using subtilisin BPN'.

**AAA is abbreviation for amino acid autoanalyzer. 
Table 18 - Effect of enzyme concentration on hydrolysis of protein in fish products ${ }^{*}$

\begin{tabular}{|c|c|c|c|}
\hline $\begin{array}{l}\text { Enzyme Concen- } \\
\text { tration } \mathrm{mg} / \mathrm{ml}\end{array}$ & $\begin{array}{l}\text { Amount of Enzyme } \\
\text { Used - ml }\end{array}$ & $\begin{array}{l}\text { Substrate } \\
\mathrm{FP}_{1} \text { - mg }\end{array}$ & $1 / 2 \mathrm{Cys}$ \\
\hline 0.5 & 1 & 50 & 0.24 \\
\hline 1.0 & 1 & 50 & 0.28 \\
\hline 2.0 & 1 & 50 & 0.32 \\
\hline 5.0 & 1 & 50 & 0.31 \\
\hline 10.0 & 1 & 50 & 0.32 \\
\hline 20.0 & 1 & 50 & 0.35 \\
\hline
\end{tabular}

*Hydrolysis was conducted in O.IM imidazole buffer $\mathrm{pH} 7.0$ at $37 \mathrm{C}$ for 18 hours using subtilisin BPN'. 
Table 19 - Effect of suspended particles on determination of TAA in protein hydrolyzate of fish products ${ }^{*}$

Particular of

Experiment
Substrate $\mathrm{FP}_{1} \quad$ Amount of $\mathrm{mg}$
Subtilisin

$\mathrm{mg}$

$1 / 2$ Cys

50

10

0.35

particles

50

10

0.34

* Protein was hydrolyzed in 0.1M imidazole buffer ( $\mathrm{pH} 7.0)$ at $37 \mathrm{C}$ for 18 hours. 
Table 20 - Effect of urea concentration on determination ${ }_{*}$ of TAA in protein hydrolyzate of fish products ${ }^{*}$

\begin{tabular}{|c|c|c|c|}
\hline $\begin{array}{l}\text { Urea } \\
\text { Concentration }\end{array}$ & $\underset{\mathrm{mg}}{\text { Substrate }}-\mathrm{FP}_{1}$ & $\begin{array}{l}\text { Subtilisin } \\
\text { mg }\end{array}$ & $1 / 2 \mathrm{Cys}$ \\
\hline $4 \mathrm{M}$ & 50 & 10 & 0.32 \\
\hline $8 \mathrm{M}$ & 50 & 10 & 0.35 \\
\hline $16 \mathrm{M}$ & 50 & 10 & 0.35 \\
\hline
\end{tabular}

*Protein hydrolyzates prepared in 0.1M imidazole buffer (pH 7.0) at $37 \mathrm{C}$ for 18 hours. 
Table 21 - Optimum temperature for hydrolyzing protein from fish products with subtilisin BPN ${ }^{*}$

\begin{tabular}{ccccc}
\hline & \multicolumn{4}{c}{ Protein } \\
$\begin{array}{c}\text { Temperature } \\
(\mathrm{C})\end{array}$ & $\mathrm{FP}_{7}$ & $\mathrm{FP}_{8}$ & $\mathrm{FP}_{9}$ & $\mathrm{FP}_{11}$ \\
\hline 37 & 70 & 73 & 57 & 57 \\
43 & 75 & 77 & 63 & 63 \\
50 & 87 & 82 & 77 & 66 \\
56 & 86 & 83 & 76 & 69 \\
\hline
\end{tabular}

* Protein was hydrolyzed at pH 7.0 for 3 hours using $10 \mathrm{mg}$ enzyme per $0.5 \mathrm{~g} \mathrm{FP}$. 
Table 22 - Optimum pH for hydrolyzing protein from fish products with subtilisin $\mathrm{BPN}^{*}$

\begin{tabular}{lcccc}
\hline & \multicolumn{4}{c}{ Protein Digestibility $-\%$} \\
$\mathrm{pH}$ & $\mathrm{FP}_{7}$ & $\mathrm{FP}_{8}$ & $\mathrm{FP}_{9}$ & $\mathrm{FP}_{11}$ \\
\hline 4.0 & 47.5 & 51.7 & 46.8 & 40.7 \\
5.5 & 89.5 & 92.1 & 85.5 & 79.5 \\
7.0 & 80.7 & 82.9 & 71.9 & 69.9 \\
8.5 & 61.8 & 69.5 & 54.4 & 44.9 \\
\hline
\end{tabular}

*Protein was hydrolyzed at $50 \mathrm{C}$ for 3 hours using $10 \mathrm{mg}$ enzyme per $0.5 \mathrm{~g} \mathrm{FP}$. 
Table 23 - Period of digestion of protein from fish products with subtilisin BPN *

\begin{tabular}{ccccc}
\hline $\begin{array}{l}\text { Period of } \\
\text { Hydrolysis } \\
\text { (Hour) }\end{array}$ & $\mathrm{FP}_{7}$ & $\mathrm{FP}_{8}$ & $\mathrm{FP}_{9}$ & $\mathrm{FP}_{11}$ \\
\hline 1.0 & 76.5 & 74.0 & 63.4 & 44.5 \\
3.0 & 85.2 & 84.9 & 80.9 & 74.1 \\
6.0 & 88.1 & 81.2 & 81.8 & 77.5 \\
\hline
\end{tabular}

*Protein was hydrolyzed at pH 7.0 and $50 \mathrm{C}$ using $10 \mathrm{mg}$ enzyme per $1.0 \mathrm{~g}$ FP. 
Table 24 - Enzyme (subtilisin BPN') concentration on digestibility of protein from fish products*

$$
\text { Protein digestibility - \% }
$$

Enzyme

Concentration

\begin{tabular}{rllll}
$\mathrm{mg} / \mathrm{g}$ FP & $\mathrm{FP}_{7}$ & $\mathrm{FP}_{8}$ & $\mathrm{FP}_{9}$ & $\mathrm{FP}_{11}$ \\
\hline 1.0 & 69.2 & 74.8 & 69.8 & 56.1 \\
2.0 & 77.1 & 81.4 & 72.1 & 59.2 \\
5.0 & 82.9 & 83.8 & 75.6 & 71.9 \\
10.0 & 85.2 & 84.9 & 80.9 & 74.1
\end{tabular}

*Protein was hydrolyzed at $\mathrm{pH} 7.0$ and $50 \mathrm{C}$ for 3 hours using $1.0 \mathrm{~g}$ FP. 
Table 25 - Comparison of thio amino acid content in fish products by Ionalyzer and amino acid Autoanlyzer methods

Fish Ionalyzer Method AAA Method

$1 / 2$ Cys Value of Products Cysteine $1 / 2$ Cys Cysteine $1 / 2$ Cys $1 / 2$ Cys of AAA Method

Herring

$\begin{array}{llllll}\mathrm{FP}_{7} & 0.11 & 0.364 & -- & 1.0 & 36.4 \\ \mathrm{FP}_{8} & 0.00 & 0.223 & -- & 0.6 & 37.2\end{array}$

Menhaden

$\begin{array}{llllll}\mathrm{FP9} & 0.16 & 0.44 & -- & 1.1 & 40.0 \\ \mathrm{FP}_{10} & 0.10 & 0.275 & -- & 0.85 & 32.4 \\ \mathrm{FP}_{11} & 0.00 & 0.215 & -- & 0.60 & 35.8\end{array}$

*Enzymatic hydrolysis was conducted at $50 \mathrm{C}$ and $\mathrm{pH} 7.0$ for 3 hours using $50 \mathrm{mg}$ FP. 
Table 26 - The observed potential and the change of potential on titrating the protein hydrolyzates of fish products $\left(\mathrm{FP}_{7}\right)$

Amount of $\mathrm{AgNO}_{3}$ Potential Change of Solution Added Observed Potential $\mathrm{ml}$ $\mathrm{mV} \quad \mathrm{mV}$

Remarks

\begin{tabular}{|c|c|c|c|c|}
\hline (a) & $\begin{array}{l}0.0 \\
0.1 \\
0.2 \\
0.3 \\
0.4 \\
0.5\end{array}$ & $\begin{array}{l}250 \\
250 \\
255 \\
270 \\
280 \\
285\end{array}$ & $\begin{array}{r}0 \\
0 \\
5 \\
20 \\
30 \\
35\end{array}$ & $\begin{array}{l}\text { Fifty mg FP7 was hydrolyzed } \\
\text { in } 49 \mathrm{ml} \text { imidazole buffer } \\
\text { (pH } 7 \text { ) with } 1 \mathrm{ml} \text { of } 10 \mathrm{mg} / \mathrm{ml} \\
\text { subtilisin BPN for } 3 \text { hours } \\
\text { in a thermostatically con- } \\
\text { trolled magnetic stirrer } \\
\text { incubator under N2 atmos- }\end{array}$ \\
\hline (b) & $\begin{array}{l}0.0 \\
0.1 \\
0.2 \\
0.3 \\
0.4 \\
0.5 \\
0.6 \\
0.7 \\
0.8 \\
0.9 \\
1.0\end{array}$ & $\begin{array}{l}330 \\
330 \\
330 \\
330 \\
330 \\
330 \\
335 \\
340 \\
355 \\
360 \\
360\end{array}$ & $\begin{array}{r}0 \\
0 \\
0 \\
0 \\
0 \\
0 \\
5 \\
10 \\
25 \\
30 \\
30\end{array}$ & $\begin{array}{l}\text { phere. The hydrolyzates were } \\
\text { titrated with AgNO3 (0.00IM). } \\
\text { (a) This was unreduced hy- } \\
\text { drolyzate to determine } \\
\text { cysteine (R-SH). } \\
\text { (b) This was after lst re- } \\
\text { duction with .05 mg NaBH } 4 \\
\text { to estimate the amount of } \\
\text { AgNO3 solution to be added } \\
\text { before 2nd reduction. }\end{array}$ \\
\hline (c) & $\begin{array}{l}0.0 \\
0.1 \\
0.2 \\
0.3 \\
0.4 \\
0.5 \\
0.6 \\
0.7 \\
0.8\end{array}$ & $\begin{array}{l}305 \\
305 \\
305 \\
305 \\
310 \\
310 \\
315 \\
330 \\
335\end{array}$ & $\begin{array}{r}0 \\
0 \\
0 \\
0 \\
5 \\
5 \\
10 \\
25 \\
30\end{array}$ & $\begin{array}{l}\text { (c) To the acidified ( } \mathrm{pH} 3-4) \\
\text { hydrolyzate after lst re- } \\
\text { duction } 0.5 \mathrm{ml} \text { AgNO3 solutior } \\
\text { was added and the final } \\
\text { titration was conducted as } \\
\text { usual after second reduction. } \\
\text { The equivalence points were } \\
\text { obtained from the Fig. No. } 1 .\end{array}$ \\
\hline
\end{tabular}




\section{$\mathrm{V}$}

\section{DISCUSSION}

\section{General}

The thiol amino acids are very sensitive to moist heat, alkalies and even atmospheric oxygen. Autoxidized fat deteriorates TAA beyond the level of -SS groups, and thereby they lose the property of thiol aminoacids. These reactions have been reviewed earlier. If the TAA content can be utilized as a basis for measuring the quality of fish products, it would be possible to determine the process steps that affect quality.

Thiol amino acids should include both cysteine and cystine. Cystine is composed of two molecules of cysteine. Both of them are reported as $1 / 2$ cystine ( $1 / 2$ cys in $\%$ ) in acid hydrolysis method using an amino acid autoanalyzer, which is an accepted standard method. Both of them are put together as TAA. In addition, it is better to compare the result of a newly developed method with the results of an accepted standard method.

Numerous works on the determination of the amino acid composition of proteins have used the "acid hydrolysis method" and "enzymatic hydrolysis method." In this work, an Ionalyzer with $\mathrm{Ag} / \mathrm{S}$ specific-ion electrode has been combined with enzymatic hydrolysis to develop a new method to determine the 
TAA in protein in fish products. The new method has been named the "Ionalyzer method." The results of the analysis of TAA from the proteins of fish products obtained by the Ionalyzer method have been compared with those obtained with the acid hydrolysis method using an amino acid autoanalyzer. The latter method is abbreviated herein as the "AAA Method."

Fish Product Definitions

"Fish meal" is any product prepared from fish and fish wastes by reducing the moisture content below a certain level, which is usually below $10 \%$ to make the product more stable, with respect to its keeping quality, than the raw materials from which it has been prepared. Fish meals normally contain 6-10\% moisture, 5-12\% fat, 60-75\% protein and 10-20\% ash [Sparre, 1965]. Fish Protein Concentrate (FPC) on the other hand, is any stable, wholesome product of high nutritive quality, hygienically prepared from fish in which the protein and other nutrient materials are more concentrated than they were in fresh fish [Stillings and Knoble, 1971]. There is no difference between FPC, type $B$, and fish meal when they are hygienically manufactured from fresh fish. However, there is a difference between FPC type A and fish meal. The composition of FPC type $A$ and $B$ are prescribed by the Protein Advisory Group of PAG [FAO/WHO/UNICEF-1971]. The protein, moisture, fat and ash contents in FPC type A are $>75 \%$, $\angle 10 \%, \angle 0.5 \%$ and $\angle 0.5 \%$ (acid insoluble) and for type $B$ $>60.0 \%$, <10\%, no limit and $<0.5 \%$ respectively. The 
specification made by the Food and Drug Administration of the United States for FPC is more stringent than that of the PAG of the United Nations. The former prescribed that FPC must be made from hake or hake-like fish. Protein, moisture, fat, ash and flouride contents must be $>75 \%,<10 \%,<0.5 \%$ and $<100 \mathrm{ppm}$ respectively. In addition, the iso-propanol and ethylenedichloride levels should be less than $100 \mathrm{ppm}$ and 5 ppm respectively [Federal Register, 1967].

The newly developed method for determining TAA in fish protein can be used on both fish meal and FPC to observe the effects of various types of processing on fish protein. Moreover, the products prepared do not qualify as FPC type A or FPC as prescribed by the US-FDA, but they possess the quality of FPC type B and fish meal. The products prepared for use in this study have been termed "fish products" (FP).

Selection of Fish

Both herring and menhaden are important commercial species used for the production of fish meal in the United States. Clupea ilisha (Hamilton) [Bhuiyan, 1964] is an important similar commercial species in Bangladesh. This latter species belongs to the herring family. Hence, these two species were selected for the study.

Selection of Methods for Processing Fish for Evaluation of Nutritional Quality of Fish Products

Two methods of processing fish to products were used. In one method, water content and polar fats in ground raw 
fish were extracted at room temperature with methanol. Then methanol was removed by azeotropic distillation with short chain aliphatic hydrocarbons $\left(\mathrm{C}_{6}\right.$ or $\mathrm{C}_{7}$ ) as azeotrope formers. In this way, the process temperature could be controlled. Two factors, moisture and heat, are responsible for the deterioration of TAA. In this process, moisture is reduced to less than $10 \%$ before the fish protein is subjected to heat for distillation. The temperature required for distillation of methanol azeotropically with heptane does not rise above 59.1 C. Hexane forms an azeotrope at a much lower temperature $(50 \mathrm{C})$ with methanol. This has two beneficial effects. The product is subjected to a low temperature and minimum energy is consumed. It will be easy to recover methanol from methanol-water-oil miscella as it does not form an azeotrope with water. All other alcohols possess a lower capacity for the extraction of moisture and polar fats and form azeotropes at much higher temperatures with the above mentioned hydrocarbons. When higher molecular weight alcohols are used, the fish proteins are subjected to higher temperatures and more destruction of TAA may occur.

The second method used in producing fish product is the wet reduction method. The meal and a press-cake used in this study were manufactured from menhaden by this method by Lipman Marine Inc. The press-cake was converted to a product $\left(\mathrm{FP}_{10} \mathrm{O}\right)$ and the menhaden meal was also obtained from the above mentioned company. The menhaden meal was used as standard product and the control in feeding tests. 
Selection of Method for Hydrolyzing Protein in Fish Products

There are three methods of hydrolyzing proteins, e.g., acid, alkaline and enzymatic hydrolysis methods.

Acid hydrolysis requires 24 hours for digestion of protein with $6 \mathrm{~N}-\mathrm{HCl}$. To remove free $\mathrm{HCl}$ from the hydrolyzates at $40 \mathrm{C}$ requires a long time and under acidic condition $\mathrm{HCl}$ bound to $-\mathrm{NH}_{2}$ of amino acid may be set free and interfere in titrating - $\mathrm{SH}$ groups with $\mathrm{AgNO}_{3}$. In addition, the inorganic bases form chlorides as the - $\mathrm{NH}_{2}$ groups of amino acids do and the chlorides are not removed during distillation of free HCl from the hydrolyzate. In high concentration, chlorides may interfere in titration of $-\mathrm{SH}$ with $\mathrm{AgNO}_{3}$ solution. Hence the acid hydrolysis method was not considered suitable for the Ionalyzer Method.

Alkaline hydrolysis of protein [Tannenbaum et al., 1970] was rejected on the ground that alkalies destroy sulfur containing amino acids [Abel et al., 1927]. Alkalies also cause racemization of the amino acids [Block, 1945]. This method of hydrolyzing FP was also rejected.

Enzymatic hydrolysis. Various proteolytic enzymes have been used to hydrolyze proteins by many workers [Clandinin, 1949; Hale, 1969; Sen, et al., 1962]. There are several disadvantages to their use among which are: (1) the hydrolysis seldom goes to completion; (2) many days are often required to get satisfactory digestion; (3) enzymes are proteins and often undergo partial autolysis with the result that a portion of amino acid to be determined may have been 
derived from the enzyme preparation itself [Block, 1945]. In spite of these inherent difficulties, this method was adopted because there was the possibility of less destruction of thiol amino acid and the least interference in titrating -SH groups with $\mathrm{AgNO}_{3}$ solution.

Selection of Enzyme for Hydrolyzing Fish Products

The enzymes are proteins. Most of them contain either cysteine or cystine, or both. They also will be accounted for in the titration along with the TAA of the protein hydrolzates. As the proteins are not, generally, completely hydrolyzed by enzymatic method of digestion, it may be difficult to find out the proportion of TAA liberated by hydrolyzing the protein. Therefore, it was necessary to find a protease which is devoid of cysteinyl and/or cystinyl residues. The proteases subtilisin [Ottesen and Svendsen, 1970] and collagenase [Seifter and Harper, 1970] do not contain these groups. Therefore, these two enzymes were selected to hydrolyze the fish products.

The Effects of Processing on Fish Proteins

Chemical properties of fish products

The bound water content in cod fish tissue is about 9.5\% [Love, 1968]. The moisture content of fish meal and FPC should not exceed $10 \%$ in either case. The moisture content of ground fish can be reduced below 10\% by extracting twice with methanol using the ratio of alcohol to wet ground fish at 1:1 by weight [Meade, 1973]. The moisture content 
of menhaden press-cake varies between $50-60 \%$. So the presscake was also dehydrated in a similar manner. The moisture content of fish products has been reported herein as total volatiles (T.V.) in percentage.

T.V. content was below $10 \%$ (Table 2) in all fish products but FP7 and FP8. The level of T.V. was also very close to $10 \%$ in $\mathrm{FP}_{7}$ and $\mathrm{FP}_{8}$ as shown in that table. The moisture content in menhaden meal produced by wet reduction method was only $1.1 \%$.

The tissue materials are reluctant to give up bound water easily. So, it is more difficult to reduce the moisture level below the level of bound water of the tissues. The reason for reducing moisture content below $10 \%$ level is to prevent the growth of microorganisms and minimize spoilage of the products.

Fat content of fish meal and FPC type A should not exceed $12 \%$ and $0.5 \%$ respectively. The fat content of fish products has been reported in Table 2. The fat content of $\mathrm{FP}_{4}$ and $\mathrm{FP} 6$ were close to $0.5 \%$ The fat content of $\mathrm{FP}_{5}$ was very high, at $20.8 \%$, and it was prepared intentionally with that amount of lipid to note the effect of its autoxidation on -SH. The fat content in all other samples were below $12 \%$, the level of fat often found in fish meal. The level of lipid can be reduced by altering the amount of solvent, period of extraction, temperature and other process conditions such as stirring and amount of miscella removed by pressing. 
Protein content of fish products (Table 2) prepared from herring $\mathrm{FP}_{1}-\mathrm{FP}_{8}$ were above $75 \%$ except in $\mathrm{FP}_{5}$ where it was $68.2 \%$ It was because the fat content was kept high. The protein content in products prepared from menhaden (FP9-FPlI) were low, 64-66\%. This indicates that herring can be used to prepare FPC with a good amount of protein. The head of this species may be discarded to insure the proper level of protein. But in case of menhaden, both head and backbone should be discarded to prepare fish products with high protein level. There was no difference in the level of protein due to differences in process conditions.

Ash content of fish products (Table 2) made from herring was close to $10 \%$. Menhaden products contained $20-23 \%$ ash due to their high bone content. The composition of amino acids of the fish products $\mathrm{FP}_{1}, \mathrm{FP}_{3}-\mathrm{FP}_{6}$ prepared in the preliminary experiments from herring are shown in Table 3 . The differences in the level of amino acids due to differences in processing are minimal except for cystine. The levels of cystine were higher in the products prepared at lower temperature with lower fat content than those products prepared at higher temperature and higher fat content.

The composition of amino acids of the fish products $\mathrm{FP}_{7}$ and $\mathrm{FP}_{8}$ prepared from herring and fish products, $\mathrm{FP}_{9}-\mathrm{FP}_{11}$ prepared from menhaden are shown in Table 3. The amino acids: Arg, Cys, Lys, Met, Phe, Ser and Tyr, were slightly lower in $\mathrm{FP}_{8}$ than they were in $\mathrm{FP}_{7}$

The amino acid composition of $\mathrm{FP}_{9}, \mathrm{FP}_{10}$, and $\mathrm{FP}_{11}$ made 
from menhaden shown in Table 3, indicated that the Cys, His, Lys, Met in $\mathrm{FP}_{9}$ are higher than in either $\mathrm{FP}_{10}$ or $\mathrm{FP}_{11}$.

Four of the five products $\left(\mathrm{FP}_{7}-\mathrm{FP}_{10}\right)$ were prepared with great care and used for feeding tests to observe the effect of processing on fish protein. The fifth product, FPII which was a commercial fish product was used as a control in the feeding tests.

The Effect of Processing on Nutritional Quality

The nutritional quality of fish products (FP7-FPlI) was evaluated by a bio-assay method using a 10-day chick feeding test. Tests were conducted with two types of diets: Experimental diets with 21\% protein, and (2) Experimental diets with $18 \%$ protein. There were five rations (DI-D5) supplemented with five types of fish products. The level of fish products in each ration supplied $4 \%$ protein. The levels of amino acids essential for chick growth were calculated in each ration. The results are shown in Tables 11 and 12 . The recommended levels of amino acids essential for chick growth are also shown in Tables 11 and 12 [NAS, 1971]. It was observed that the amino acid level except SAA in the 21\% protein diets met the requirements prescribed by the National Academy of Sciences. On the other hand, the requirements of essential amino acid for chick growth fell short in the diets with $18 \%$ protein. The methionine and cystine levels provided were only 50-60\% of the level recommended by NAS. The supplementation of poultry diets with more than $5 \%$ of 
fish meal is seldom possible. Bird, et al. [1965], in evaluating fish meal quality with chicks fed a diet supplemented with $4 \%$ fish meal obtained variable growth responses. It was shown by Clandinin [1949] that by supplementing the diets with a 10\% level of fish meal that the herring meal dried at higher temperatures had a lower nutritive value than those dried at a lower temperature. The identical conclusion was drawn by Yanez, et al. [1970].

In the experimental diets containing $21 \%$ protein, it was observed that the non-oxidized fish product, $\mathrm{FP}_{7}$, produced better results than the oxidized fish product $\mathrm{FP}_{8}$ in chick growth as determined as feed conversion efficiency. Both of those were prepared from the same stock of herring. It was also noted that the product prepared from menhaden at low temperature, $\mathrm{FPg}$, produced better feed conversion ratio by chicks than that of the commercially manufactured menhaden meal, $\mathrm{FP}_{11}$. The product prepared from menhaden press-cake,

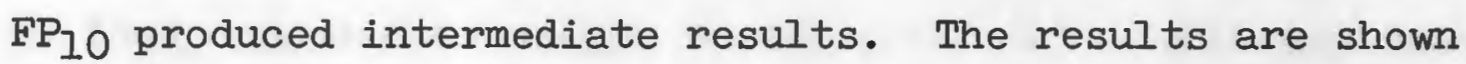
in Table 10 (a).

There was no significant difference in $\mathrm{F} / \mathrm{G}$ between $\mathrm{FP}_{7}$ and $\mathrm{FP}_{8}$ when the level of protein in the diet was 18\%. The $\mathrm{F} / \mathrm{G}$ results when menhaden products, $\mathrm{FP}_{9}-\mathrm{FP}_{11}$, were incorporated in the $18 \%$ protein diets showed the same trend as they did in the $21 \%$ protein diets.

This indicates that the fish products prepared azeotropically from fresh fish were better than a commercial 
product or the products prepared from the fish cakes in which fats were autoxidized. The product prepared from commercially prepared menhaden press-cake had a better nutritive value than the commercial menhaden meal, but lower nutritive value than the product prepared azeotropically from fresh fish of the same species.

The nutritive value of FPC prepared by azeotropic solvent extraction method using methano'l-heptane was compared with the nutritive value of FPC prepared with IPA extraction and FPC prepared with dichloroethane-IPA by rat feeding test [Nikkila, 1972]. She found that the nutritional quality of FPC prepared by methanol-heptane was superior to the products produced by the other two methods. Hence it can be assumed from the results of the rat feeding tests that the FPC prepared azeotropically with methanol and a short chain hydrocarbon (heptane) will prove to be a better food supplement.

In the "Experimental diets (2l\% protein)," the ratio of feed consumed to weight gained per chick in a 10-day feeding test was higher in ration D2 (1.49) than that of ration D1 (1.40). In the same Experimental diets, the ratio of feed consumed to weight gain per chick in a 10-day feeding test was higher in D5 (1.54) than that of either D3 (1.45) or D4 (1.46) (Table 10-a).

In the "Experimental diets (18\% protein)," similarly, the ratio of feed consumed to weight gain per chick in a 10-day feeding test was not significantly higher wih ration D2 (2.24) than that of the ration D1 (2.23). The ratio of 
feed consumed to weight gain per chick was higher in ration D5 (2.29) than of either ration D3 (2.15) or ration D4 (2.19) (Table 10-b).

The interesting result obtained in the feeding test was that the ratios of feed consumed to weight gain per chick in a 10-day feeding test were higher in rations D2 and D5 than those of the rations D1 and D3. The ration D2 was formulated with the product prepared azeotropically after dehydrating the ground herring followed by oxidation of lipids in atmosphere at ambient temperature. The ration D5 was formulated using menhaden meal, which was subjected to both moist heat and autoxidation of lipids at higher temperatures. The ration Dl was formulated using the product prepared azeotropically after dehydrating ground herring with methanol at room temperature (26-28 C) and the ration D3 was formulated with the product prepared from fresh menhaden, similar to the product made from herring for ration $\mathrm{Dl}$. The ration $\mathrm{D} 4$ was formulated with the product produced azeotropically after dehydrating the commercially manufactured menhaden presscake with methanol at ambient temperature. It was observed that the nutritive value had been reduced by both moist heat, as in the product used in formulating ration D4. However the nutritive quality was reduced to the greatest degree by interaction of the products of lipid autoxidation with protein in both herring and menhaden. 
Estimation of Thiol Amino Acids by Ionalyzer Method

The thiol amino acids were determined by the method of Harrap and Gruen [1971] from the hydrolyzates of $\mathrm{FP}_{1}$ and $\mathrm{FP}_{3}-\mathrm{FP}_{6}$. The results are presented in Table 17 along with corresponding results obtained by AAA method. The TAA values for $\mathrm{FP}_{1}$ and $\mathrm{FP}_{4}$ were close (25\% and 20\%), for $\mathrm{FP}_{5}$ and $\mathrm{FP} 6$ also close (12\% and $14.3 \%$ ) but those were lower than those of $\mathrm{FP}_{1}$ and $\mathrm{FP}_{4}$. These differences, possibly, were due to the fact that $\mathrm{FP}_{1}$ and $\mathrm{FP}_{4}$ were made at lower temperatures than the $\mathrm{FP}_{5}$ and $\mathrm{FP}_{6}$ which were prepared by drying the raw ground fish at $95 \pm 5 \mathrm{C}$ for 18 hours. The comparative $1 / 2$ cystine value of $\mathrm{FP}_{3}$ in Ionalyzer method was $32.7 \%$ of that of AAA method but it was not far off from the value of $\mathrm{FP}_{1}$. The hydrolyzates were prepared by using $1 \mathrm{ml}$ of $10 \mathrm{mg} / \mathrm{ml}$ subtilisin BPN' per $50 \mathrm{mg}$ substrate in $24 \mathrm{ml} 0.1 \mathrm{M}$ imidazole buffer $\mathrm{pH} 7$ for a period of 18 hours. This was done following the method of pepsin digestibility (AOAC, 1970]. The pH of the buffer was adjusted to $\mathrm{pH} 7.0$.

The effect of concentration of enzyme, the effect of suspended particles, and concentration of urea in the hydrolyzates were studied. The 1/2 cystine value obtained from the hydrolyzates with 2-20 mg enzyme/50 mg of substrate were similar. The cystine value obtained in $0.5 \mathrm{mg}$ enzyme/ $50 \mathrm{mg}$ substrate was definitely low. One $\mathrm{mg}$ enzyme/50 mg of substrate produced an intermediate value (Table 18).

The suspended particles ( $\mathrm{Table} 19$ ) and the concentrations of urea ( $4 \mathrm{M}, 8 \mathrm{M}$ or $16 \mathrm{M}$ ) (Table 20), did not change 
the value of $1 / 2$ cystine in hydrolyzates. This indicated that suspended particles produced no interference in titrating - $\mathrm{SH}$ groups with $\mathrm{AgNO}_{3}$. Urea denatures soluble proteins and peptides and unfolds them thus allowing determination of -SH groups. The different concentrations of urea produced a result similar to that without urea, which indicates that there might not be any long chain polypeptides. All these experiments were conducted with $10 \mathrm{mg}$ enzyme/50 mg substrate $\left(F P_{1}\right)$.

The optimum temperature and $\mathrm{pH}$ of hydrolysis, and the digestibility for various periods of hydrolysis and the concentration of subtilisin on $\mathrm{FP}_{7}-\mathrm{FP}_{9}$ and $\mathrm{FP}_{11}$ were studied and the results are reported in Tables 21-24. The optimum temperature was between 50-56 C. The optimum $\mathrm{pH}$ was between 5.5 and 7.0. pH 7.0 was used in the hydrolysis of fish products because the buffering action of imidazole is close to $\mathrm{pH}$ 7.0. There was little difference in hydrolyzation between 3 and 6 hours, but there was a low hydrolyzability in 1 hour. Similarly, there was little difference in hydrolyzability of enzyme with $5 \mathrm{mg}$ or $10 \mathrm{mg} / 50 \mathrm{mg}$ substrate. But $1 \mathrm{mg}$ enzyme/50 mg substrate was lower. Two $\mathrm{mg} / 50 \mathrm{ml}$ substrate produced intermediate results.

Considering the lower value of TAA obtained in the Ionalyzer method in comparison to the AAA method, the length of the period of hydrolysis and the different percentages of hydrolysis of fish product, the fish products were hydrolyzed for a period of three hours in a nitrogen atmosphere 
using the same enzyme (subtilisin BPN') at $10 \mathrm{mg} / 50 \mathrm{mg}$ substrate at $50 \mathrm{C}$ in $0.1 \mathrm{M}$ imidazole buffer ( $\mathrm{pH} 7.0$ ) with a total volume of hydrolyzate of $50 \mathrm{ml}$. The $1 / 2$ cystine value was determined following the method described earlier.

The TAA was determined quantitatively by both AAA and Ionalyzer methods from the fish products $\mathrm{FP}_{7}-\mathrm{FP}_{11}$. The results are shown in Table 25. It appears that the TAA as $1 / 2$ cys (\%) obtained in the Ionalyzer method was about $36 \%$ (32-40\%) of the value obtained in the AAA method in hydrolyzates produced in a three hour hydrolysis under nitrogen atmosphere. The $1 / 2$ cystine value of $\mathrm{FP}_{8}$ was $60 \%$ of the 1/2 cystine value of $\mathrm{FP}_{7}$ in the AAA method. The 1/2 cystine value of $\mathrm{FP}_{8}$ was also $61 \%$ of the $1 / 2$ cystine value of $\mathrm{FP}_{7}$ in the Ionalyzer method. Both the products are from herring. The $1 / 2$ cystine value of $\mathrm{FP}_{10}$ and $\mathrm{FP}_{11}$ were $77 \%$ and $55 \%$ of the $1 / 2$ cystine value of $\mathrm{FP}_{9}$ respectively in the $\mathrm{AAA}$ method. At the same time the $1 / 2$ cystine values of $\mathrm{FP}_{10}$ and $\mathrm{FP}_{11}$ were $63 \%$ and $49 \%$ of the $1 / 2$ cystine value of $\mathrm{FP}_{9}$ respectively in the Ionalzyer method. All of the products were from menhaden.

It was observed that 10-15\% of TAA obtained by the AAA method could be accounted as cysteine by direct titration with $\mathrm{AgNO}_{3}$ solution in the fish products processed from fresh fish and the commercially prepared fish cake using the simultaneous azeotropic distillation and extraction method. Cysteine could not be detected either in 
autoxidized product prepared from herring nor in commercialIy prepared menhaden meal. It was observed that the fish products having titratable cysteine values produced better F/G than those which had no titratable cysteine value. 
CONCLUSIONS AND RECOMMENDATIONS

\section{Conclusions}

1. The fish products produced by alcohol dehydration and simultaneous azeotropic distillation and lipid extraction, with less than 5\% residual lipid content, retained more thiol amino acids than products produced by a method with more than $12 \%$ lipids or by dehydrating whole ground fish in the oven at a temperature of $95 \pm 5 \mathrm{C}$.

2. Fish products prepared from fresh herring by alcohol dehydration followed by simultaneous azeotropic distillation and lipid extraction had higher TAA levels than a product prepared from fresh herring by alcohol dehydration followed by autoxidation of lipid at ambient temperature for 5 weeks.

3. The level of TAA in the menhaden product produced by alcohol dehydration and simultaneous azeotropic distillation and lipid extraction were higher than those present in a commercial menhaden meal. The TAA level in menhaden meal was 55\% lower than that in the azeotropically produced product. The TAA values as $1 / 2$ cystine were 0.6 and $1.0 \%$ respectively.

4. The product prepared from menhaden press-cake by alcohol dehydration followed by simultaneous azeotropic 
distillation and lipid extraction had an intermediate TAA value. The three menhaden products: fish meal, press-cake. processed azeotropically, and raw fish processed azeotropically had $1 / 2$ cystine levels of $0.6,0.85$, and $1.1 \%$ respectively.

5. Cooking, as carried out in the wet reduction process, accounts for approximately $50 \%$ of the reduction of TAA when menhaden fish meal is produced by the wet reduction method.

6. The TAA level in alcohol dehydrated ground whole fresh herring from which the lipids were not extracted but allowed to autoxidize at ambient temperature for 5 weeks was $50 \%$ lower than the level in a similar product that was alcohol dehydrated followed by simultaneous distillation and lipid extraction.

7. Cysteine was available for titration with $\mathrm{AgNO}_{3}$ in products prepared from fresh herring and menhaden and menhaden press-cake when they were dehydrated with alcohol followed by simultaneous distillation to remove alcohol and extract lipids. Cysteine was not available for titration in a commercial menhaden meal and in a product prepared from fresh herring by alcohol dehydration in which the lipids were allowed to autoxidize for 5 weeks at ambient temperature.

8. The results of chick feeding studies in which it was attempted to show a correlation between the biological response and chemical and biochemical determinations for TAA were disappointing. The practical formulas employed 
(18 and 21\% protein) were sub-optimal with respect to SAA but the quantity provided by the $4 \%$ protein derived from the fish products was not adequate to provide a clear cut response. There were indications that products prepared from fresh herring and menhaden by alcohol dehydration and simultaneous distillation to remove alcohol and extract lipids were superior to products prepared from menhaden press-cake, oxidized herring and menhaden fish meal. A more sensitive bio-assay procedure will be required to show a positive correlation.

9. Subtilisin BPN' proved to be more suitable for the solubilization of the fish products studied than collagenase, another protease devoid of -SH and -SS- groups.

10. The optimum conditions for the solubilization of fish products with the protease subtilisin BPN' in 3 hours were established as: temperature, 50-56 C; pH, 5.5-7.5; and enzyme substrate ratio $10 \mathrm{mg}: 50 \mathrm{mg}$.

11. The minimum effective level of subtilisin BPN' required for adequate solubilization of fish products was $2 \mathrm{mg} / 50 \mathrm{mg}$ of fish product.

12. Non-solubilized portions of the substrate remaining after enzymatic hydrolysis were found to have no adverse effect on thiol titration.

13. Urea when present at a concentration of $4.0,8.0$ and $16.0 \mathrm{M}$ did not affect the TAA values determined in fish product hydrolyzates.

14. The level of TAA in protein hydrolyzates prepared 
from fish products ranged between $32-40 \%$ of the level established by the AAA method of analysis.

15. Imidazole was found to be the most suitable buffer for use in the $\mathrm{AgNO}_{3}$ titration of -SH groups in fish protein hydrolyzates.

16. The Ionalyzer method for determining the thiol content of fish products can be carried out in from 4-5 hours. The time required for determining $1 / 2$ cystine by the AAA method is about 40 hours and it is not possible to differentiate between -SH and -SS- groups.

\section{Recommendations}

1. The TAA ( $1 / 2$ cys $\%$ ) values in protein hydrolyzates of the fish products made in a 3 hour digestion period using the enzyme subtilisin BPN' in the Ionalyzer method were 32-40\% lower than those using the AAA method. Subject to further studies, it appears that the probable causes of the low TAA in the Ionalyzer method are either: (a) incomplete hydrolysis of protein in the products; (b) oxidation of -SH and -SS- groups beyond the level of -SS- by residual oxygen in the buffer and the flask; (c) the interaction of -SH and -SS- groups with the products of autoxidized lipids; (d) complex formation between available metallic ions and - $\mathrm{SH}$ groups present in the hydrolyzates or their synergistic actions. Further work is necessary on these points.

2. The experiments were conducted using the enzymes having no -SH and/or -SS- groups to avoid difficulties in 
separating the amount the TAA contributed by the enzyme and the protein of fish products. The suitability of using enzymes containing -SH and -SS- groups for hydrolyzing protein in fish products should be studied.

3. The bio-assay experiments conducted in this study showed, although it was not conclusive, that the fish products prepared by dehydrating the fresh or frozen ground fish with methanol at ambient temperature followed by removal of methanol by azeotropic distillation produced better ratios of feed consumed to weight gained by chicks in a 10-day test. It is, therefore, suggested that more bio-assay experiments be conducted to determine the degree of correlation that exists between TAA level and the growth response of selected test animals.

It needs to be proven conclusively that the fish products produced by dehydrating fish with alcohol followed by removal of alcohol by azeotropic distillation and of fat by extraction with hydrocarbons $\left(\mathrm{C}_{6}, \mathrm{C}_{7}\right.$ or any other suitable one), products which retain more TAA, also produce more growth than the fish products produced by conventional wet reduction method. 
REFERENCES

Abel, J.J., E.M.K. Geiling, C.A. Rouiller, F.K. Bell and 0. Wintersteiner. 1927. Crystalline insuline. J Parmacol. Exptl. Therap. 31:65.

Ambrose, M.E., B.J. Roche and G.M. Knoble. 1969. Semimicro method for determining total lipids. J.A.O.A.C. $52: 688$.

Ammerman, G.R. 1957. Influence of equal lethal heat treatments at various temperatures on food quality. Ph.D. Dissertation, Purdue University, Lafayette, Indiana.

Annon. 1952. Heat stability of amino acids in stickwater. In Fish Meal, a comprehensive bibliography. NOAA-1970, U.S. Com., Washington, D.C.

Anslow, G.A. and E.R. Layman. 1941. Spectrophotometric study of glutathione. J. Optical Soc. Am. 31:114.

AOAC. 1970. Official methods of analysis. Assoc. Offic. Anal. Chemists, Washington, D.C.

A.O.C.S. 1964. Official and tentative methods. Official final action. Ed. 8, p. 53.

Balls, A.K. and H. Lineweaver. 1939. Nature of group in papain essential to its activity. Nature 144:513.

Barlow, S.M. and F.W. Burton. 1973. The roll of fish meal in alleviation of protein shortage in human nutrition. Presented in Technical Conference on Fishery Products, Tokyo, Japan.

Benesch, R., and R.E. Benesch. 1948. Amperometric titration of sulfhydryl groups in amino acids and proteins. Archv. Bioch. 19:35.

Beuck, J.F., F.W. Chornock, and E.E. Rice. 1948. The effect of sever heat treatment upon the amino acids of fresh and cured pork. J. Biol. Chem. 175:291.

Bhuiyan, A.L. 1964. Fish of Dacca, p. 9. Asiatic Society of Pakistan, Dacca.

Bird, H.R., T.W. Sullivan, N.L. Karrick and C.R. Grau. 1965. Two methods of evaluating fish meal protein by chick growth. Poul. Sci. 44:865. 
Block, R.J. 1945. The amino acid composition of food proteins. Adv. Prot. Chem. 2:119.

Block, R.J. and D. Boiling. 1944. Nutritional opportunities with amino acids. J. Am. Diet. Assoc. 20:69.

Bock, R. and H.J. Puff. 1968. Measurement of sulfide with a sulfide-selective membrane electrode. Z. Anal. Chem. $260: 381$.

Braddock, R.J. and L.R. Dugan, Jr. 1973. Reaction of autoxidizing linoleate with coho salmon myosin. J.A. O.C.S. $50: 343$.

Burton, H. 1958. The Amperometric titration of fulfhydryl groups at rotating platinum electrode. Bioch. et Biophy. Acta. 29:193.

Buttkus, H. 1972. The reaction of malonaldehyde on oxidized linolenic acid with sulfhydryl compounds. J. A.O.C.S. 49:613.

Cecil, R. and J.R. McPhee. 1959. Sulfur chemistry of proteins. Adv. Prot. Chem. 14:225.

Clandinin, D.R. 1949. The effects of methods of processing on the nutritive value of herring meals. Poul. Sci. $28: 128$.

Dann, J.R., G.L. Oliver, and J.W. Gates, Jr. 1957. The reaction of cystine and lanthionine with aqueous calcium hydroxide. J. Am. Chem. Soc. 79:1644.

Dean, W.F. and H.M. Scott. 1965. Development of an amino acid diet for the early growth of chicks. Poul. Sci. $46: 803$.

Dreosti. G.M. 1973. Future of powdered fish products. Presented in the Technical Conference on Fishery Products, Tokyo, Japan.

Dunn, M.S., N.C. Merritt, S. Eiduson, and R.B. Malin. 1949. Nutritive value of canned foods. I. Amino acid content of fish and meat products. J. Nutr. 39:177.

Durst, R.A. 1969. Ion selective electrodes. Publication No. 314. National Bureau of Standards, Washington, D.C.

FAO/WHO/UNICEF. 1971. Fish protein concentrate. PAG guideline No. 9. The United Nations, N.Y.

Federal Register. 1967. Whole fish protein concentrate. F.R. 121.1202, Feb. 2, U.S.F.D.A. 
Feeny, R.E. and R.M. Hill. 1960. Protein chemistry and food research. Adv. Food Res. 10:23.

Fletcher, K.S. and R.F. Mannion. 1970. Electrochemical generation of silver (I) through silver sulfide membranes. Anal. Chem. 42:285.

Friodovich. I. and P. Handler. 1947. Colorimetric assay for reaction of sulfhydryl groups with organic mercurials. Anal. Chem. 29:1219.

Fromageot, C. and G. Schenck. 1950. Le spectre ultraviolet du lysozyme. Biochem. et Biophy. Acta. 6:113.

Gilman, A., F.S. Fillips and E.S. Koelle. 1946. The renal clearance of thiosulfate with observations on its volume distribution. Am. J. Physiol. 146:348.

Grau, C.R. and M.A. Williams. 1955. Fish meal as amino acid source in chick ration. Poul. Sci. 34:810.

Gruen, L.C. and B.S. Harrap. 1971. Determination of thiols with specific-ion electrode. Anal. Bioch. 42:377.

Gruenwedel, D.W. and R.K. Patnaik. 1971. Release of hydrogen sulfide and methyl mercaptan from sulfur containing amino acids. J. Agr. Food Chem. 19:775.

Gurd, F.R.N. and P.E. Wilcox. 1956. Complex formation between metalic cations and proteins, peptides and amino acids. Adv. Prot. Chem. 11:312.

Hale, M.B. 1969. Relative activities of commercially available enzymes in the hydrolysis of fish protein. Food Tech. 23:107.

Harmes, R.H. and B.L. Damron. 1969. Protein and sulfur amino acids requirements of the laying hens as influenced by dietary formulation. Poul. Sci. 48:144.

Harrap, B.S. and L.C. Gruen. 1971. Application of a specificion electrode to the determination of disulfide groups in proteins. Anal. Bioch. 42:398.

Herz, K.O. and S.S. Chang. 1970. Meat flavor. Adv. Food Res. 18:1.

Hellerman, L. 1937. Reversible inactivation of certain hydrolylic enzymes. Physiol. Rev. 17:454.

Hellerman, L., F.P. Chinard and P.A. Ramsdel. 1941. O-iodosobenzone acid, a reagent for the estimation of cysteine, glutathione, and the substitutent - $\mathrm{SH}$ groups of certain proteins. J. Am. Chem. Soc. 63:2551. 
Hellerman, L., F.P. Chinard and V.R. Deitz. 1943. Protein sulfhydryl groups and the reversible inactivation of the enzyme urease. J. Biol. Chem. 147:443.

Homolka, J. 1971. Polarography of proteins. Analytical principles and applications in biological and clinical chemistry. Meth. Bioch. Anal. 19:435..

Hughes, R.B. 1964A. Chemical studies on herring. J. Sci. Food Agr, 15:290.

Ingram, V.M. 1955. Sulphydryl groups in haemoglobins. Biochem. J. 59:653.

Jenness, R. and S. Patton. 1959. In Principles of dairy chemistry. John Wiley and Sons, Inc., New York.

Kolthoff, I.M. and B.R. Willeford. 1957. A stable equimolar copper II - albumin complex. J. Am. Chem.

Soc. $79: 2656$.

Kolthoff, I.M. and J. Eisenstadter. 1961. Amperometric argentometric and merucurimetric titration of sulfyhydryl. Anal. Chim. Acta. 24:83.

Kuninori, T. and B. Sulivan. 1968. Disulfide-sulhydryl interchange studies of wheat flour. Cereal Chem. $45: 486$.

Larson, B.L. and R. Jenness. 1950. The determination of protein sulfhydryl groups with iodine and idosobenzonote by an amperometric titration. J. Dairy Sci. $20: 890$

Lewis, S.E. and E. Wills. 1962. The destruction of -SH groups of proteins and amino acids by peroxides of unsaturated fatty acids. Bioch. Pharm. 11:901.

Lightbody, H.D. and H.L. Fevold. 1948. Shelf life of dried whole eggs. Adv. Food Res. 1:149.

Love, R.M. 1968. Ice formation in frozen muscle. In Low temperature biology in foodstuffs, p. 118. J. Hawthorn and E.F. Rolfe, eds. Pergamon Press, New York.

Matsuo, N. 1957B. Study on the toxicity of fish oils; the effects of autoxidized ethylester of highly unsaturated fatty acid on protein and amino acid. J. Japan Bioch. Soc. 29:773.

Meade, T.L. 1973. Preservation and extraction process for production of fish meal. U.S. Patent No. 3712822. 
Mecchi, E.P., E.L. Pippen and H. Lineweaver. 1964. Origin of hydrogen sulfide in heated chicken muscle. J. Food Sci. 29:393.

Meredith, P. 1965. The oxidation of AsA and its improved effect on bread dough. J. Sci. Food Agr. 16:474.

Merritt, C. and J.M. Mendelsohn. 1962. Flavor of fish. Paper presented before the Division of Agriculture and Food Chemistry, American Chemical Society, 142nd National Meeting, Atlantic City, N.J.

Miller, D. and R.R. Kiefer. 1970. Factor affecting protein evaluation of fish meal by chick bioassay. Poul. Sci. 49:999.

Minor, L.F., A.M. Pearson, L.E. Dowson, and B.S. Schweigert. 1965B. Chicken Flavor. J. Food Sci. 30:686.

Moore, S. 1963. On the determination of custeic acid. J. Biol. Chem. 233:235.

Muller, D.C., P.W. West, and R.H. Muller. 1969. Determination of silver in parts per billion range with a selective ion electrode. Anal. Chem. 4l:2038.

NAS. 1968. Nutrient requirements of swine. Pub. No. 2, National Academy of Science, Washington, D.C.

1971. Nutrient requirements of poultry. Pub. No. 1, National Academy of Science, Washington, D.C.

1972. Nutrient requirements of laboratory animals. Pub. No. 10, National Academy of Science, Washington, D.C.

Naumann, R. and C. Weber. 1971. Titration of sulfide with a sulfide selective electrode. Z. Anal. Chem. 253:111.

Neilands, J.B., R.J. Sviny, I. Sohljell, F.M. Strong, and C.A. Elvehjem. 1949. The nutritive value of canned foods. II. Amino acid content of fish and meat products. J. Nutr. 39:187.

Nikkila, E.M. 1972. Utilization of fish protein concentrate for human consumption. M.S. Thesis, University of Rhode Island.

Orion Research Inc. 1972. Analytical methods guide. 4th ed. Cambridge, Mass. 
Osborne, T.B. and L. Mendel. 1914. Amino Acid in nutrition and growth. J. Bio. Chem. 17:325

Ottesen, M. and I.B. Svendsen. 1972. The subtilisin. Methods in enzymology. 19:1.

Perlman, G.E. and L. Lorand. 1970. The cystine proteases. Methods in Enzymology. 19:226.

Rice, E.E. and J. Beuk. 1953. The effects of heat upon the nutritive value of protein. Adv. Food Res. 4:233.

Roberts, J.D. and M. C. Caserio. 1965. In Basic principles of organic chemistry, page 747 . W. $\bar{A}$. Benjamin, Inc., New York.

Rose, W.C. and R.L. Wixome. 1955. Amino acid requirements of man. J. Biol. Chem. 216:763.

Rose, W.C., R.L. Wixome, H.G. Lockhart, and G.F. Lambert. 1955. The amino acid requirements of man. J. Biol. Chem. 217:987.

Roubal, W.T. and A.L. Tappel. 1966. Damage to proteins, enzymes and amino acids by peroxidizing lipids. Arch. Bioch. and Biophy. 113:5.

Sasse, C.E. and D.H. Baker. 1973. Availability of sulfur amino acids in corn gluten meal for growing chicks. Anim. Sci. 37:135.

Seifter, S. and E. Harper. 1970. Collageneses. Methods in Enzymology. 19:613.

Sen, D.P., N.V. Sripathy, N.L. Lahiry, A. Sreenivasan, and V. Subrahmanyan. 1962. Fish hydrolysates: I rate of hydrolysis of fish flesh with papain. Food Tech. 16:138.

Singer, T.P. 1946. Enzyme inhibitors and the active groups of protein. Brewers Digest 20:85.

Sluyterman, L.A.E. 1957. The amperometric titration of sulfhydryl groups with silver nitrate. Bioch. et Biophy. Acta. 25:402.

- 1966. Amperometric argentometric titration of thiol groups in imidazole buffer. Anal. Bioch. 14:317.

Soares, J.H. and R.R. Kiefer. 1971. Evaluation of protein quality based on residual amino acids in ideal content of chicks. Poul. Sci. 50:41. 
Sparre, T. 1965. Fish meal: manufacture, properties and utilization. In Fish as food, Vol. III, p. 4II. G. Borgstrom, ed. Academic Press, New York.

Stillings, B.R. and G.M. Knoble, Jr. 1971. Fish protein concentrate: A new source of dietary protein. J. Am. Oil Chem. Soc. 48:412.

Stockland, W.L., R.L. Meade, D.F. Wass, and J.E. Sowers. 1973. Influence of level of methionine and cystine on the total sulfur amino acids requirment of the growing rat. Anim. Sci. 36:526.

Sullivan, B.J. 1954. Proteins in flour. Reviews of the physical characteristics of gluten and reactive groups involved in change in oxidation. J. Agr. Food Chem. $2: 1231$.

Sullivan, M.X., W.C. Hess, and H.W. Howard. 1942. The quantitative estimation of both cystine and cysteine in mixture. J. Biol. Chem. 145:62l.

Sutherland, G.B.B.M. 1951. Spectroscopy and molecular structure. Faraday Soc., Discussion 9.

Tarbell, D.S. and D.P. Harnish. 1951. Cleavage of carbonsulfur bond in divalent sulfur compound. Chem. Rev. 49:1.

Tannenbaum, S.R., M. Ahren and R.P. Bates. 1970. Solubilization of fish protein concentrate. I. An alkaline process. Food Tech. 24:96.

Technicon Corporation Inc. 1967. Instruction manual for amino acid autoanalyzer. Technicon Corporation, New York.

Tsao, T.C. and X. Bailey. 1953. The extraction, purification and some chemical properties of actin. Biochem. et.Biophy. Acta. 11:102.

West, W.S., W.R. Todd, H.S. Mason, and J.T. Bruggen. 1966. In Text book of Biochemistry. 14th Edition. MacMillan Co., London

Willard, H.H., L.L. Merritt, Jr., and J.A. Dean. 1969. In Instrumental methods of analysis, p. 542. 4th Edition. D. Van Nostrand Co., Inc., Princeton, N.J.

Yanez, E., D. Ballester and G. Donoso. 1970. Effect of drying temperature on quality of fish protein. $J$. Sci. Food \& Agr. 21:426. 
APPENDIX A

Procedure for determining cysteine and cystine (TAA) in the protein hydrolyzates of fish products by Ionalyzer method.

\section{Apparatus}

(a) $\mathrm{Ag} / \mathrm{s}$ specific-ion electrode - silver ion electrode, Model 04-16.

(b) Double junction reference electrode - Model 90-02.

(c) Ionalyzer - specific-ion Meter - Model 407. All three $(a-c)$ were from Orion Research Inc., Cambridge, Massachusetts.

(d) $\mathrm{pH}$ meter

(e) Microburette $-5.0 \mathrm{ml}$ with 0.01 divisions

\section{Reagents}

(a) Subtilisin BPN' - (Sigma Chemical, St. Louis, Missouri) - prepare enzyme solution in boiled and cooled distilled water.

(b) Silver nitrate (A.R.) - 0.001 M (or a suitable strength

(c) $\mathrm{Na}_{2}$ EDTA - $0.1 \mathrm{M}$

(d) Octanol

(e) $\mathrm{N}_{\mathrm{a}} \mathrm{BH}_{4}$ A.R.

(f) Imidazole buffer 0.1 M solution in distilled water dissolve $6.8 \mathrm{~g}$ imidazole in $900 \mathrm{ml}$ water. Neutralize with $4 \mathrm{M} \mathrm{HNO}_{3}$ to $\mathrm{pH} 7.0$ and make the volume to 1 liter.

(g) $\mathrm{HNO}_{3}$ - concentrated, A.R.

(h) $\mathrm{HNO}_{3}$ - acetone solution ( $\mathrm{HNO}_{3}$ :acetone:I:Iv/v) 


\section{Procedure}

(a) Fish proteins - if the protein contains $5.0 \%$ lipids, wash $50 \mathrm{~g}$ of it three times with $100 \mathrm{ml}$ of hexane or heptane stirring properly for 15-20 minutes and after each wash remove the miscella preferably by filtration or centrifuging at $1000 \mathrm{x}$ G for 15 minutes. Desolventize the product and grind it in "Hammer Mill" using 60 mesh screen.

(b) Hydrolysis with enzyme - to 50-100 mg of ground fish product add $1 \mathrm{ml}$ of $0.1 \mathrm{M}$ imidazole buffer $(\mathrm{pH} \mathrm{7.0)}$ and $1 \mathrm{mg}$ of fish product previously warmed to $45-48 \mathrm{C}$ in a 250 $\mathrm{ml}$ Erlenmyer flask. Bubble nitrogen gas (free from $\mathrm{O}_{2}$ ) for 15 minutes. Add $1 \mathrm{ml}$ of enzyme solution of required strength; stopper the flask immediately after removing the nitrogen gas capillary tube to minimize the exposure of the mixture in the flask to oxygen in the air. Hydrolyze in a $50 \mathrm{C}$ shaker incubator or in a $50 \mathrm{C}$ magnetic-stirrer incubator for 3 hours.

Determine TAA as per method of Harrap and Gruen [1971], using $\mathrm{Ag} / \mathrm{S}$ specific-ion electrode and standardized $\mathrm{AgNO}_{3}$ solution. The amount of $\mathrm{AgNO}_{3}$ solution needed can be obtained from the titration curve. The curves prepared from the hydrolyzates of $\mathrm{FP}_{7}$ by plotting the amount of $\mathrm{AgNO}_{3}$ required versus the change in potential are shown in Figure 1. The amount of $\mathrm{AgNO}_{3}$ needed for titration can be obtained from the respective curves. 


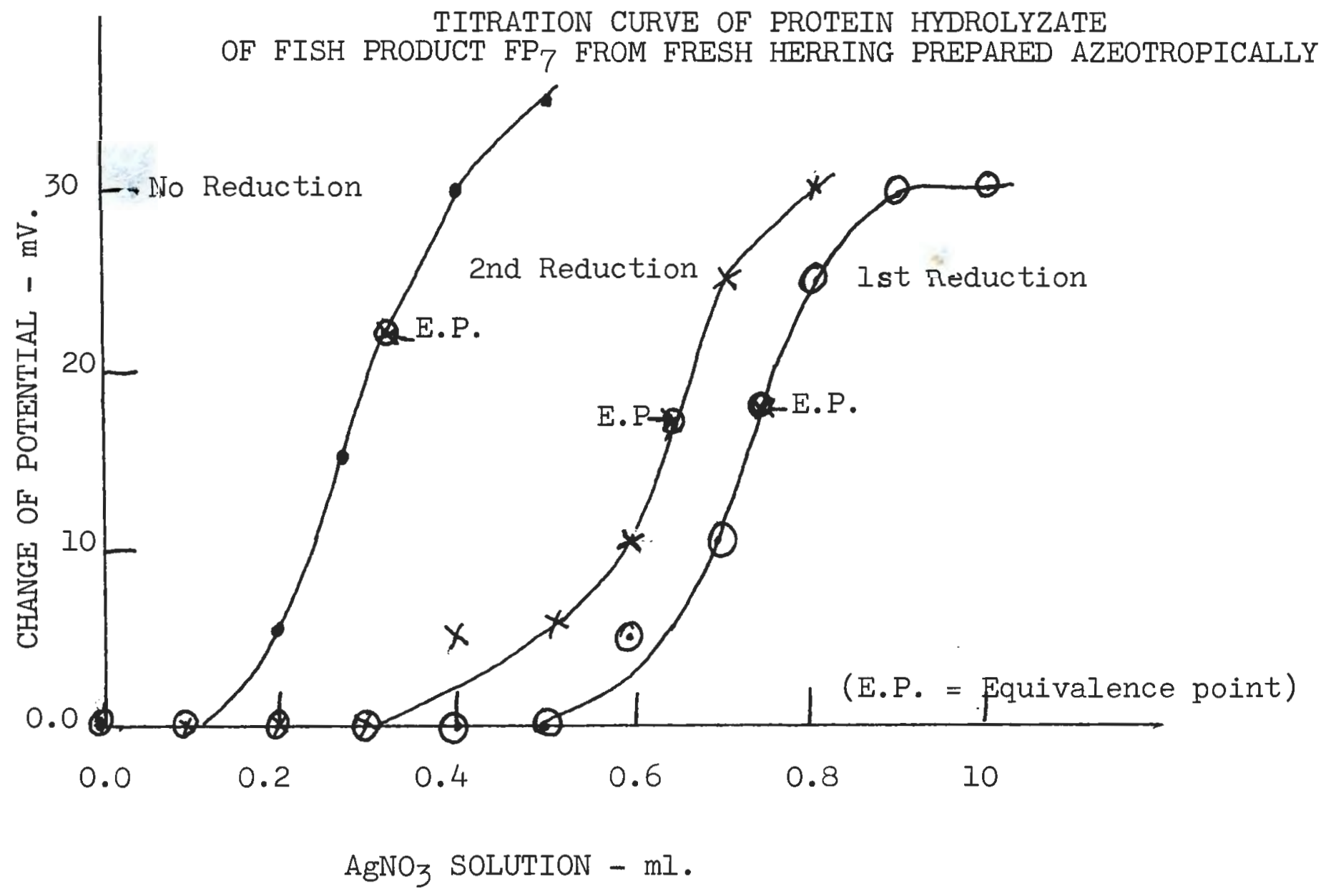

FIGURE 1 